\title{
Global demand for certified hardwood products as determined from a survey of hardwood exporters
}

\author{
Ellen E. Hrabovsky \\ West Virginia University
}

Follow this and additional works at: https://researchrepository.wvu.edu/etd

\section{Recommended Citation}

Hrabovsky, Ellen E., "Global demand for certified hardwood products as determined from a survey of hardwood exporters" (2003). Graduate Theses, Dissertations, and Problem Reports. 1762.

https://researchrepository.wvu.edu/etd/1762

This Thesis is protected by copyright and/or related rights. It has been brought to you by the The Research Repository @ WVU with permission from the rights-holder(s). You are free to use this Thesis in any way that is permitted by the copyright and related rights legislation that applies to your use. For other uses you must obtain permission from the rights-holder(s) directly, unless additional rights are indicated by a Creative Commons license in the record and/ or on the work itself. This Thesis has been accepted for inclusion in WVU Graduate Theses, Dissertations, and Problem Reports collection by an authorized administrator of The Research Repository @ WVU. For more information, please contact researchrepository@mail.wvu.edu. 


\title{
Global Demand for Certified Hardwood Products As Determined from a Survey of Hardwood Exporters
}

\author{
Ellen E. Hrabovsky
}

Thesis submitted to the Davis College of Agriculture, Forestry and Consumer Sciences

at

West Virginia University in partial fulfillment

of the requirements for the degree of

\author{
Master of Science \\ In \\ Forestry (Wood Science)
}

\author{
James P. Armstrong, Ph.D., Chair \\ Ray R. Hicks, Jr., Ph.D. \\ R. Bruce Anderson, Ph.D.
}

\section{Division of Forestry}

Morgantown, West Virginia

2003

Keywords: certified hardwood products, forest certification, international hardwood markets, hardwood trade 


\section{ABSTRACT \\ Global Demand for Certified Hardwood Products As Determined from a Survey of Hardwood Exporters}

\section{Ellen E. Hrabovsky}

United States hardwood exporters were surveyed to determine the current international markets for certified hardwood products (CHWP) and to document the experiences of hardwood exporters concerning CHWP and certification. There was a $42 \%$ response rate to the 265 mailed surveys. Twenty six percent of exporting companies received requests for CHWP. These requests represented $<5 \%$ of the companies total export business. The experiences of the responding exporters parallels that reported in previously published studies. Willingness to pay a premium is low. Over half of the exporters indicated that customers will not pay any premium. Chain of custody issues are a major problem and the supply of certified hardwood lumber is small. Only large companies owning their own forests have no problem with certification, chain-of-custody documentation or supply. The markets remain predominantly niche markets centered in northern Europe. China is emerging as a major market for primary CHWP. 


\title{
DEDICATION
}

\author{
To \\ Larry O’Neill \\ My beloved Grandfather \\ and \\ First Forestry Professor
}

You are always with me especially in the forest. 


\section{ACKNOWLEDGEMENTS}

Funding support for this study was provided under the Hatch Act by the Agricultural and Forestry Experimental Station.

I am extremely grateful to my committee members, Drs. Ray Hicks and Bruce Armstrong, for their support and encouragement throughout my forestry education and during this project. Dr. Jingxin Wang taught me to use Microsoft Access and helped me organize this data. I am grateful for all his help and encouragement. Dr. James Armstrong, mentor and friend, made all this possible. His sage counsel and guidance and his never failing sense of humor make him the ideal advisor and teacher.

Last but not least I must give my heartfelt thanks to my two dearest friends Sue (my sister) and Jo. They have provided unfailing support, encouragement and love through my long and sometimes difficult journey. 


\section{TABLE OF CONTENTS}

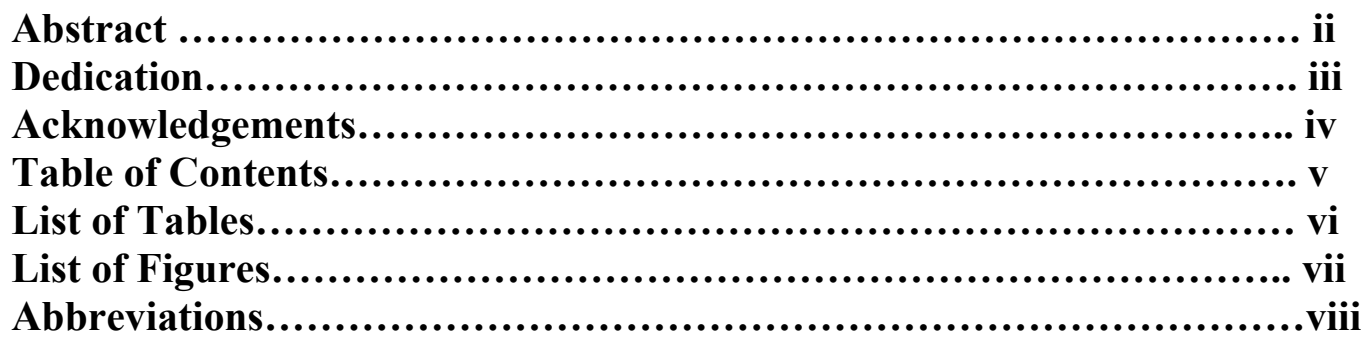

Chapter1 Introduction and Study Objectives................................1

Introduction..................................................... 1

Study Objectives............................................... 2

Chapter 2 Review of Literature............................................... 3

Certification Systems............................................3

Ecolabels..........................................................5

Benefits of certification.............................................5

Chain-of-custody issue.........................................5

Cost of Certification..............................................6

Markets...............................................................7

Willingness to pay (WTP) and consumer attitudes.............7

WTP - United States experience.............................8

WTP - European experience...................................9

WTP - New Zealand..........................................10

Business and Manufacturer Attitudes.......................... 11

Summary of Literature.......................................12

Chapter 3 Study Methods and Survey......................................13

Survey instrument............................................13

Non-response bias..............................................14

Data Management............................................14

Chapter 4 Results...............................................................16

Certification and Certification Schemes........................16

Markets for CHWP...........................................18

Adequacy of Supply.........................................18

Importance ranking............................................19

Willingness to pay a premium.................................19

Internet influence.................................................20

Chapter 5 Discussion..........................................................22

Chapter 6 Conclusions and Recommendations...............................27

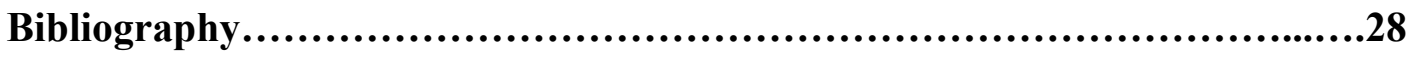




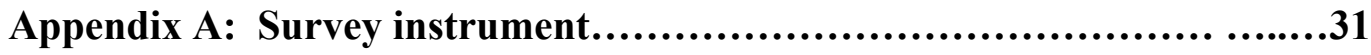

Appendix B: Letter of introduction to exporters..........................35

Appendix C: Follow-up letter to exporters.....................................37

Appendix D: Tables And Figures...........................................39

Appendux E Curriculum Vitae.............................................54 


\section{LIST OF TABLES}

Table 1 Total and certified forest acres - global and United States........40

Table 2 Timberland ownership in the United States.....................41

Table 3 Willingness to pay estimates from cited surveys.................42 


\section{LIST OF FIGURES}

Figure 1 Ecolabels of SCS and FSC................................43

Figure 2 Ecolabels of SFI and American Tree Farm..................43

Figure 3 Distribution of hardwood exporters........................44

Figure 4 Survey response............................................45

Figure 5 Non-response bias.........................................46

Figure 6 Requests for CHWP.......................................47

Figure 7 Markets for CHWP........................................48

Figure 8 Supply, Certification Scheme and Ecolabel...................49

Figure 9 Importance ranking of lumber orders.....................50

Figure 10 Willingness to pay a premium.............................51

Figure 11a\&b Internet presence.....................................52

Figure 12 Hardwood imports by People's Republic of China.........53 


\section{ABBREVIATIONS:}

AF\&PA

CHWP

CSA

CWP

DNE

FAO

FAS

FSC

NGO

NHLA

PEFC

SCS

SFI

WTP
American Forest \& Paper Association

Certified Hardwood Products

Canadian Standards Association

Certified Wood Products

Does not export

Food and Agricultural Organization (United Nations)

Foreign Agricultural Service

Forest Stewardship Council

Non-governmental Organization

National Hardwood Lumber Association

Pan European Forest Certification

Scientific Certification Systems

Sustainable Forestry Initiative

Willingness to pay 


\section{CHAPTER 1 INTRODUCTION and STUDY OBJECTIVES}

Loss of forests and forest resources has been a concern to people since agrarian societies progressively encroached on forested land. From the eighteenth century onwards there was a growing realization that forests could be managed on a sustainable basis to provide a continuing supply of resources. Schools of forestry, studying the management of forests as a crop, originated in Europe to develop sustainable forest practices (Peck 2001). Forest conservation was not an issue to the early settlers of North America because of the seemingly endless tracts of forest; however, by the late nineteenth century removal of forests for agricultural acreage and a variety of forest products became a serious concern. By 1900 much of the eastern United States was deforested giving rise to the conservation agenda of Theodore Roosevelt's administration. Large tracts of once forested land were put into reserves to be managed for timber as a crop and to preserve watersheds. By the 1960's the conservation movement, which espoused wise usage, was being challenged by an environmental agenda advocating preservation for biodiversity and multiple uses of forested land other than timber production. World-wide, destruction of tropical rain forests in the latter half of the $20^{\text {th }}$ century, stimulated by increasing population and the need for agricultural land, spurred environmentalist action (Floyd et al. 2001).

Thus arose the concept of "sustainable forestry". 'Beginning with the Earth Summit in 1992, sustainable development has been the focus of international resource discussions.' (Hendricks 2003) The search for a useful and mutually agreeable definition is not as easy as the term may sound. A widely recognized definition of sustainable forestry arising from the Pan European/Helsinki Process is: 'the stewardship and use of forests and forest land in a way and at a rate, that maintains their biodiversity, productivity, regeneration capacity, vitality and their full potential to fulfill, now and in the future, relevant ecological, economic, and social functions, at local, national and global levels and does not cause damage to other ecosystems.' (Peck 2001) Oliver (2003) provides a useful working definition of sustainable forestry found in the concept of 'environmental justice' stating "that people living in one place and time should provide their 'fair share' of 
values - neither unfairly exploiting nor depriving themselves of certain values to the detriment or benefit of people in another place or time."

Forest certification is the process by which forest owners voluntarily submit their forests to inspection by an independent certification body to determine whether their management meets clearly defined standards, particularly in regard to sustainability (Peck 2001). "The objective of certification is to link the informed consumer with products produced in an environmentally and socially responsible manner." (Carbarle et al.1995) Multiple certification schemes now exist, competing for the market share of the CWP (certified wood product) business.

\section{STUDY OBJECTIVES}

Forest certification will encompass an ever increasing number of acres only if: a) the consumer values the concept of sustainable forestry and views certification as an added quality of the product to be purchased; b) the producers of forest products think certification is important and, most important; c) the producers of CWP have a market for their products. To place the issue of supply and demand for CWP in a current, global context this study of U.S. hardwood exporters' experiences was designed to answer the following questions: [Hardwood exporters were targeted in this study because the U.S. is the second largest hardwood exporter in the world, second only to Malaysia (Peck 2001)]

- Who in the international export market is asking for certified hardwood products (CHWP)?

- Is the supply of CHWP adequate?

- What certification schemes do international buyers request?

- Is there a willingness to pay (WTP) a premium for CHWP?

- Are the markets for CWP shifting from Northern Europe where they began? If so, where are the new markets?

- Where do consumers rank the importance of certification in relation to other product and service attributes?

- Is an ecolabel important to the consumer? 


\section{CHAPTER 2 REVIEW OF LITERATURE}

\section{CERTIFICATION SYSTEMS}

The realization in the 1980's that tropical deforestation was reaching alarming levels led to multiple plans for combating tropical forest loss. The first wave of reaction was in support of boycotts of tropical timber when in fact only $19 \%$ of the tropical timber harvest reached the world's markets. In 1993 a number of non-governmental environmental groups, including the Rainforest Alliance, Greenpeace, the World Wildlife Fund and Friends of the Earth, concerned about the loss of tropical rain forest established the Forest Stewardship Council (FSC). "Its goal is to support environmentally appropriate, socially beneficial, and economically viable forest management" (Smouts 2003). FSC attempted to bring together environmental and human rights groups and representatives of the timber industry and trade in a common cause. Their focus was meant to reward exemplary forest management in a global context while considering both the environment and social values. FSC does not certify directly but evaluates, accredits and monitors other certification organizations which in turn inspect and grant ecolabels.

In the United States, the American Tree Farm System was established in 1941 as the earliest forest certification system, but it was not until 1993 that certified forestry really developed to the point that Ecolabeling of certified products was the end result(Anon 2003). The Rainforest Alliance's 'Smartwood' program and the Scientific Certification Systems (SCS) Forest Conservation Program are third party, independent certifying agencies under the umbrella of FSC. The Smartwood program evaluates specific timber harvest operations on sustained yield, ecosystem and wildlife maintenance and financial and social considerations; whereas the SCS Forest Conservation program involves indepth evaluation of specific timber harvesting operations (Vlosky and Ozanne 1995).

It was the opinion of many American foresters and representatives of the American forest industry that the goals and objectives of FSC did not adequately reflect American forestry practices and were unacceptable. Consequently, alternative programs developed such as the Sustainable Forestry Initiative (SFI) introduced by the American Forest and Paper 
Association (AF\&PA). The SFI program targets the active management of forests while protecting associated values such as wildlife, water quality, reforestation, and aesthetics. SFI certification is a condition of membership in the AF\&PA and tends to target large industry owned forests. To encourage continuing improvement in forestry practices SFI certification must be renewed periodically.

World-wide many have voiced objections to the vague, unscientific and unmeasurable principles of FSC. This gave way to the development of industry-based certification systems such as the Sustainable Forest Management Standards through the Canadian Standards Association (CSA) in 1996. In 1999 private landowners in six European countries developed the Pan European Forest Certification (PEFC) to counteract the discrimination by FSC against small and medium operations. Many other countries such as Malaysia, New Zealand, Ghana and others formed systems and alliances to provide scientific criteria and indicators for sustainable forestry and to assure market connection for their products. Each of these standards is unique to the locale; however, the concepts of protecting ecosystems, maintaining biodiversity and ensuring sustainability are a consistent thread running through all of them. Globally PEFC is the largest certification program with 109 million certified acres followed by FSC with 85 million acres (6 million in the US). The CSA has certified 36 million acres. (Table 1, page 40)

In the United States there are approximately 510 million acres of timberland or $67 \%$ of the forested area of the country (Smith 2002). Non-industrial private ownership of timberland made up 58\% of U.S. timberland or 295 million acres (Smith 2002; Brooks 1993 ) and about $72 \%$ of the hardwood resource is on non-industrial private land (Refer to Table 2, page 41 for ownership information). SFI is the largest certification system in the U.S. with 77 million third-party certified acres, which includes members of the AF\&PA and other large enterprises. The American Tree Farm System has 95 million acres enrolled with 26 million certified acres, representing 1.6\% of private US landowners with 10 or more acres (Rickenbach 2002; Berg and Olszewski 1995; Anon, 2003). 
Despite endless competition among certifying agencies only $2.5 \%$ of the world's forests are certified (Oliver 2002; Smouts 2003). In the United States, 7.5\% of forests (Smith 2002) are certified. The prominent certification schemes in the United States are The American Tree Farm System, SFI and the FSC certification and labeling program.

\section{ECOLABELS}

The Environmental Protection Agency in 1993 defined certification as an environmental label, or ecolabel, used to communicate information to the consumer. Ecolabels can be issued by first- (producers), second- (trade associations) or third- (independent agencies) party certification organizations. Ecolabeling programs use two frameworks: a) evaluation of a product or practice to meet particular specifications and b) evaluation of a management system's ability to produce a desired outcome (Carbarle et al. 1995). Some form of mark or label is attached to the product to provide information to the consumer about the origin and management of the product. Figures $1 \& 2$ (page 43) illustrate the labels or logos of prominent U.S. certification schemes.

\section{BENEFITS OF CERTIFICATION}

The presumed benefits to the producer of forest certification include proof of performance, access to markets that favor certified products and potential price premiums for 'green labeled' products (Carter and Merry 1998). These benefits depend upon a ready market and a supply adequate to feed that market. In recent years many companies have developed and promoted products with more benign environmental effects. The retail sector most affecting the sale of eco-friendly wood products is the home improvement industry. Lober and Eisen (1995) describe the policies developed by Home Depot, Inc. in establishing the most extensive environmental program in its industry. Other companies in the U.S. and abroad are beginning to follow Home Depot's example, such as IKEA, B\&Q (UK) and Lapeyre. (Smouts 2003)

\section{CHAIN-OF-CUSTODY ISSUE}

One requirement of certification is the need to maintain an audit trail from harvested log to final product. This trail progresses through many layers of production. Of the several 
problems that have developed in the handling of certified, or ecolabeled, forest products chain-of-custody documentation from the forest to the retailer can be expensive and complicated. SCS and FSC both state that products must be labeled to assure the consumer that the wood has come from a properly managed and certified forest. Buckley and Ansell (2000) studied a large sawmilling company in Pennsylvania buying logs from local suppliers within 25-100 miles to minimize transportation costs, representing about 800 small private forest owners. The technical difficulty of ensuring separation of certified and uncertified material in the sawmill and dimension plant is enormous when one considers that in this one yard 104 sorts take place in the green chain without consideration for separating certified from non-certified wood. On the other hand, large companies who own their own forests such as the Seven Islands Land Company find that chain-of-custody documentation imposes no extra burden on the mill (McNulty and Cashwell 1995).

Vlosky and Ozanne (1995) recommend a bar code system that allows tracking of all products for both inventory and certification chain-of-custody purposes. Many companies already use this technology for inventory purposes and it can be modified to keep CWPs separately identified from the non-certified. These bar codes are analogous to vehicle license plates. Each bar code is unique and can be linked to unlimited information regarding the unit to which it is attached. The information may include producer, manufacturing location, date, dimension information and certifying agency. The initial expense of this technology may be prohibitive for some operations.

\section{COST OF CERTIFICATION}

Certifying a forest management operation involves several costs: the incremental cost of complying with required practices, the cost of the assessment or audit and follow-up inspections, and the cost of identifying and monitoring the product (chain-of-custody). The cost of certification is generally borne by the forest owners with little chance to recover these costs. These costs may run from $\$ 10,000$ to $\$ 100,000$ depending on the certifying organization and the size of the forest (Mater 1995). Murray and Alt (2001) suggest that per acre costs of obtaining certification are quite small for large ownerships 
( $\$$ \$0.50/acre) but may be large for smaller ownerships not enjoying economies of scale. Because much of U.S. timberland is held in small units the cost of certification is significant. If certification is to achieve the goal of "promoting long-term forest sustainability, a forest land owner must capture a price premium for primary forests products such as logs, allowing them to recover costs of becoming certified and maintaining certification" (Stevens et al. 1998).

\section{MARKETS}

Another motive for certification is the belief that the public is really interested in purchasing items that are eco-friendly and not harmful to the environment (Mater 1995). Mater also noted that niche markets were developing in 1995, but no mass market had yet evolved. Most of the published studies identify a segment of the surveyed populations both in the United States and various northern European countries who profess an interest in certified wood products (CWP) (Ozanne and Vlosky 1997; Ozanne and Smith 1998; Grönroos and Bowyer 1999; Rametsteiner 1999; Bigsby and Ozanne 2002; Veisten 2002).

A clear pricing system for eco-labeled wood products is an important key to recouping costs. In spite of promises of an eager 'green' market, price premiums have yet to appear. Data are scarce as to actual movement and purchase of CWPs and until there are separate customs classifications for CWPs standardized reporting by country will not be possible. Markets have emerged in Germany, the United Kingdom and the Netherlands, but these are believed to be small, niche markets (Peck 2001).

\section{WILLINGNESS TO PAY AND CONSUMER ATTITUDES}

The customer's willingness to pay (WTP) for an ecolabeled product is critical to the development of necessary markets. WTP refers to the amount of money an individual would be willing to pay to secure a welfare improvement - in this case an environmental improvement. To be willing to pay more for a product the consumer must believe that the product certified as environmentally friendly is worth more than the non-certified product. Table 3 (page 42) outlines some of the published willingness to pay studies. 


\section{WTP -THE UNITED STATES EXPERIENCE}

Lober and Eisen (1995) cited an unpublished report from Purdue University stating that $68 \%$ of the respondents to a national survey said they would be willing to pay more for furniture made of materials from a sustainably managed North American forest. On average customers in this study seemed willing to spend 5-10\% more for 'green' products than for non-green ones.

A survey of American consumers done in 1995 by Ozanne and Vlosky (1997) was conducted to determine: a) the willingness of U.S. consumers to pay a price premium for CWP, b) the size of the WTP consumer segment, and c) a profile of that segment most likely to buy eco-friendly wood products. Their survey was sent to 2,500 randomly selected homeowners with annual incomes over $\$ 30,000$. Survey recipients were asked, hypothetically, to indicate their willingness to pay for a variety of wood products including 2"x 4"x 8' studs, ready-to-assemble chairs, a dining room set, kitchen remodeling costs, and a new home. Overall $2 / 3$ of the 800 respondents indicated some willingness to pay a premium. The lower the value of the product the greater was the acceptable premium; i.e. 2"x 4"x 8' stud (\$1.00 value) could carry an $18.7 \%$ premium. For a $\$ 100,000$ home the consumer would consider up to a $4.4 \%$ premium. There were a very small number of consumers who said they would pay $50 \%$ or more for CWPs because the environment was very important to them. On the other hand, $37 \%$ of consumers in this survey would not pay any premium for a certified product. As one might expect, the cluster of consumers in this study who think forest certification is very important and who are involved in environmental concerns will pay the highest premium; whereas those who do not think certification important and who are not involved will not pay a premium. This study helped to define a possible target group of purchasers of ecolabeled wood products. This niche market group, representing about 16.5 million Americans, is most likely fairly well educated, politically liberal, female Democrats belonging to an environmental organization. In another survey, Ozanne and Smith (1998) further defined distinct market segments ranging from the avid environmentalist to those who are the most suspicious of certification programs. 
Grönroos and Bowyer (1999), on the other hand, surveyed consumers who had already purchased homes in the Minneapolis and Chicago areas within the two years (1994-1995) prior to their study. A majority of survey respondents indicated that environmental impact associated with production of wood products was important when selecting building materials, but when asked to rank the importance of 14 features of the materials used, the environmental impact of building material production ranked $13^{\text {th }}$. The higher ranked features included location, price, investment value, quality of work and materials, taxes, etc. The only item ranking lower than the environment was 'house design accommodates live-in parents or children'. After considering the final financing costs of their homes only $24 \%$ of Minneapolis and 36\% of Chicago residents still would have bought CWP for their home construction. The more expensive the house the more likely the consumer was to buy CWP. In Chicago 64\% of respondents and 77\% in Minneapolis said they would not pay any premium for CWP. This study suggests that environmental concerns are not a high priority among new home purchasers in two major cities. It also illustrates that 'concern for the environment' wanes considerably when the purchase decisions are real rather than the hypothetical product choices posed by some surveys. It appears that there is a segment of the population who will pay more for CWP and this minority provides a target group for marketing.

\section{WTP - THE EUROPEAN EXPERIENCE}

In their 1997 report Ozanne and Vlosky cite studies published prior to 1995 indicating that $2 / 3$ of UK customers would pay up to $13.6 \%$ more for eco-friendly wood products. Another European study reported that $56 \%$ of consumers with annual incomes greater than $\$ 50,000$ would pay $1-10 \%$ more; $19 \%$ would pay $11-20 \%$, and $3 \%$ would exceed $20 \%$; but, on the other hand, $19 \%$ would not be willing to pay any premium. A German study found that consumers would pay an additional 5\% for CWPs. Veisten (2002) surveyed samples of the British and Norwegian populations to determine WTP a premium for ecolabeled wooden furniture. He predicted that $39 \%$ of the UK population and $32 \%$ of the Norwegian population would choose the ecolabeled furniture if the premium were less than $5 \%$. 
Rametsteiner (1999) surveyed attitudes of Europeans concerning forestry and the environment in the most prominent market countries for wood and wood products (Germany, France, United Kingdom and Italy). More than 50\% of respondents were concerned that the health of their home forests was poor and that acreage was decreasing (when in fact, it was not). However, they also thought that the most environmentally friendly products were domestic wood and glass. When assessing the effect of attitudes on purchasing practices the survey showed that environmental friendliness of a wood product is less of a determining factor than are other features. Attributes such as quality, durability, design and price ranked much higher in importance than compatibility with the environment.

Multiple studies including Rametsteiner's indicate that consumers are distrustful of industry and are much more apt to believe the environmental pressure groups, but they also will believe forestry and timber associations before they trust government reports. The manufacturer is the least trusted source of information about sustainable forestry. In the European market the majority of the CWP demand comes from companies that have committed themselves to buying certified timber products. End product consumers have not created very much significant market pressure on their own. The largest share of demand comes from the UK, the Netherlands, Belgium, and Germany. About one half of respondents expressed a willingness to pay a premium for CWPs ranging from $5.6 \%$ in France to $9.6 \%$ in Austria.

\section{WTP- NEW ZEALAND}

Bigsby and Ozanne (2002) surveyed consumers in New Zealand to determine the relative importance of environmental certification in the context of other attributes of the wood product including timber source, forest type, warranty and price. Overall the respondents were most interested in wood from New Zealand as opposed to imported wood.

Plantation grown timber, warranty and certification were next in importance with price being the least important. Cluster analysis identified four consumers groups: the 'quality environmentalist' and the 'implicit certification', the 'value-for-money' consumer and the 
'buy local' consumer. The first two groups made up $58 \%$ of the sample and are target markets for CWPs. They were not particularly price sensitive.

\section{BUSINESS AND MANUFACTURER ATTITUDES TOWARD CERTIFICATION}

Ruddell and Stevens (1998) reported that the trend toward certification in the business

and institutional furniture industry was that of a growing environmental awareness by consumers, but that interest had not yet translated into increased demand for CWP s. They also noted that no lost sales were reported as a result of not providing certified products. Vlosky and Ozanne (1997) found in their attitudinal survey of 'influencers' and 'specifiers' (contractors, architects and home centers) that these customers are generally not supportive of wood products certification. They will not incur the cost of chain-of-custody documentation and do not think their customers would pay a premium for CWP.

Stevens et al. (1998) surveyed U.S. companies selling hardwood products and companies selling FSC certified products. In spite of the low 15\% return rate of the survey, they concluded that the number one reason given for not selling CWP was that their customers were not asking for them. The second most important reason offered for not selling CWP is that companies are confident that they are buying wood from already well managed forests and that certification is superfluous. Another important reason is that the increased price is prohibitive. This study indicated that U.S. markets for FSCcertified products are small. CWP companies reported that only about $20 \%$ of their customers are interested in CWP. In terms of premium paid about $42 \%$ of sellers charged less than $3 \%$. The average charged to the buyer was $4.7 \%$. Most of the sellers have been able to pass the extra costs of CWP along to their customers. One might speculate that the very low response rate in this survey was due to lack of interest by the nonresponders.

\section{SUMMARY OF LITERATURE}

Surveys and studies from the 1990's have enumerated the conditions and problems of certification, consumer attitudes and market conditions. Multiple, competing certification 
organizations exist world wide, with as many as eight in the U.S. alone. FSC is the overriding organization in the ecolabel business. The markets are niche markets, predominantly in Northern Europe and the United States, made up of environmental enthusiasts who report they will pay significant premiums for CWPs. Studies of actual purchasing decisions are at odds with the hypothetical choices offered by many published surveys. Many authors have projected a trend in the eco-friendly forest products business of increasing interest and WTP a premium for CWP, but there is little evidence that this is occurring.

The United States is the largest exporter of temperate hardwoods in the world and the hardwood exporter has his finger, so to speak, on the world market. Therefore, this study asks the hardwood exporter: Who is asking for certified hardwood products? 


\section{CHAPTER 3 STUDY METHODS AND SURVEY}

A mail survey (Appendix A, page 31) was designed following a modification of the methods of Dillman (2000) and Salant and Dillman (1994). The hardwood exporters were asked if their international customers requested CHWP. If the answer was 'No' the survey was completed. If the answer was 'Yes', indicating requests for CHWPs, the exporter was asked to identify the geographic markets from which these requests arose, the certification scheme requested and the interest in an ecolabel. Additionally, they were asked to estimate the per cent of their business represented by the certification requests. The exporter was asked if the supply of CHWP was adequate to meet demands. The WTP a premium question was divided into four levels: $<1 \%, 1-3 \%, 3-5 \%$, and $>5 \%$. The final question in the survey asked "How does certification compare in importance to other product or service attributes such as delivery time, price, quality, availability, etc.?" Nineteen attributes of a wood product order were listed, each to be ranked in importance from 1 (least important) to 5 (most important). The exporter was offered the opportunity to receive an e-mail report of this study and was provided plenty of space for adding comments.

The contacted companies included small sawmills, distribution yards and large companies owning their own forests. Addresses and contact names for the exporters were obtained from the National Hardwood Lumber Association's (NHLA) "North American Hardwood Export Buyers Guide" (2001) and from the NHLA web site. Figure 3 (page 44) illustrates the national distribution of the surveyed exporters. The NHLA web site links provided the opportunity to determine the export status of the member company and to view their statements concerning environmental concerns. Those companies without a web site were chosen for mailing by the codes in the 'Buyers Guide' concerning type of business and the countries buying from them. A total of 265 surveys were mailed in July of 2002. The packet included a letter of introduction (Appendix B, page 35), the survey and a self-addressed postage paid envelope. Sixty eight surveys were completed and returned after the first mailing. Fifteen packets were returned as 
undeliverable. A second letter (Appendix C, page 37) and survey with post paid envelope was sent in September, 2002, to the 182 initial non-responders. Forty three exporters responded to the second mailing yielding a total response rate of $44.4 \%$. Figure 4 (page 45) illustrates the survey responses.

\section{NON-RESPONSE BIAS}

Non-response bias is a problem when a significant number of people do not respond to a survey (Pearl 1985; Grönroos and Bowyer 1999). Non-response bias, when present, means that the responding and non-responding populations are not alike. There are two methods to determine the presence of bias. The first method is to compare the first mailing responders with the responders to the later mailing to determine differences in demographics, opinions, etc. Second responders have been found to behave more like non-responders than like initial responders. Using this method, the demographics and responses were nearly identical between the first and second mailing groups, but in the first responder group only one of 68 (1.5\%) companies did not export (DNE). In the second mailing three of $43(6.9 \%)$ responders, did not export.

The second method involves random telephone queries of non-responders and comparison of their answers to the mail survey responders. To further examine the question of non-response bias, a randomly selected group of non-responders were contacted by phone and asked a modified version of the survey. In this group there was a $19 \%(4 / 20)$ DNE rate. In all other respects the responders and non-responders were identical.

Thus, there is non-response bias in this study, but the increased numbers of companies not having an export business do not invalidate the responses received from those companies that do export. It, in fact, makes the actual exporting non-responders a smaller group. If $19 \%$ of the non-responders do not export and can not answer the survey, then another 26 companies can be discarded as invalid making the adjusted response rate just over 50\%. (See Figure 5, page 46) 


\section{DATA MANAGEMENT}

The data were managed in Microsoft Access $97 \AA$ in two tables. The table labeled 'exporters' contained the company name, complete address and phone number and contact person if available. The presence or absence of a web site and the presence or absence of a positive environmental statement on that web site were recorded in this table. The response activity, i.e. first mailing, second mailing or phone contact, was recorded in the 'exporters' table. The second database table labeled 'responses' contained the responses to the survey, both mailed and random phone survey. Written comments by the exporters were stored and evaluated separately. Because the exporters were assured that the information they provided was voluntary and confidential the 'exporters' and 'response' tables are not included in this document. 


\section{CHAPTER 4 RESULTS}

One hundred eleven mailed surveys were answered and of these 29 (26\%) exporters reported that they had received requests for CHWP and four companies did not export. Four of the 20 contacts by phone acknowledged requests for CHWP making a total of 33 companies claiming CHWP requests. (See Figure 6, page 47) Twelve of the companies responding 'yes' to CHWP requests wrote comments in addition to answering the questions on the survey. Additionally, thirteen of the 78 companies that did not have requests for CHWP offered comments about forest certification. (The written comments were definitely the most informative and colorful feature of the survey.) Both groups of comments will be excerpted as they relate to survey questions.

\section{CERTIFICATION AND CERTIFICATION SCHEMES}

The exporters' comments on requests for certification ranged from "We have no interest in certification." and "It is very clear that only FSC and the environmental organizations insist that there is a major demand for certified products." to "only about $1 \%$ asks for certified and are very environmentally conscious." One eastern exporter says, "The customer cares about healthy forests but doesn't care how NGO's and the industry ensure sustainability." "I have been asked once domestically for certification on a partial load. We export about $40 \%$ of our production." Another exporter, who does not receive CHWP requests, says, "Our customers have no interest in certified products. They feel it is a push made by environmental extremists who do not understand how responsible timber companies operate nor are they interested in learning."

Some exporters are very hostile toward the entire concept of certification as stated by this exporter. "On occasion we get a request. We avoid such customers. The certification is an agenda of the left wing of the political systems in the USA and Europe. It is their way of putting a stop to our industry."

An exporter who does sell some CHWP says, "Currently certified wood products are a non-issue. However, it may become so in the future." Yet another says "Certification 
with $3^{\text {rd }}$ party certification is essential. Manufacturers that make products for Home Depot... want FSC." The summary attitude about certification may be represented by this one statement, “...we'll find only industry will promote the actual success of their sustainable initiatives and the battle over whether or not forests are sustainable will continue to waste good peoples (sic) time and money."

As described earlier there are many certification schemes operating in the United States and the world. The U.S hardwood exporters were asked which schemes were requested by their international customers. Seventeen of 33 reported specific requests and all were for FSC certified products. (Figure 8, page 49) One company noted that "Our customers want to learn about SFI, to determine if their customers will accept SFI. American SFI is in the same boat as the other European certification schemes - everyone is speculating what certification is good enough." Another comment says, "SFI is not widely known/acceptable and needs promotion." "We support the principal foundations of SFI,... We do not support FSC, period." Another respondent commented: "FSC demand is due to the fact that is has been marketed - SFI is the more scientific approach to the issue." Another company says, "Customers often change the required species to get FSC. Also music instrument manufacturers are now asking for FSC wood. Furniture and cabinet people could care less. Flooring people are now asking for 'certified' products, especially for large architectural jobs." The issue of certification schemes seems to have generated some anger in respondents. An example: "FSC is a brand - a well marketed brand. The view from FSC is non-cooperative on issues such as mutual recognition of other certification schemes, i.e.: SFI, PEFC, etc. This makes their impossibly expensive and invasive certification process unilateral and it pushes small landowners out of the loop. For producers (sawmills) that are not large landholders, this sort of economic blackmail is producing a backlash against any certification... If FSC's aim is to cover a large portion of forests in the U.S., they will only succeed in further consolidation of small land-holdings into large commercial ones. FSC attacks retailers by threatening them with 'un-green' publicity." 
As to a recognizable ecolabel one third of responders answered 'yes' customers do want the product to bear an ecolabel. The only comment was that "We present/grade our certified lumber the same way we grade our other product. However, presentation and the presence of a recognizable eco-label are important." (Figure 8, page 49)

\section{MARKETS FOR CHWP}

Data are available for 30 of the 33 exporters concerning the markets requesting CHWP. (Figure 7, page 48) Twenty four of the thirty companies receive requests from Northern Europe and most of these requests come from the United Kingdom, Germany, the Netherlands and Belgium. Southern Europe is the next most frequent market (12/30) requesting CHWP. China appears to be an emerging market and, according to exporters, requests from Chinese companies are increasing. Japan and Canada each represent 23\% of the requesting markets. An exporter from the west coast who trades only with Japan says that the Japanese are very environmentally conscious but can not and will not pay a premium so instead they buy non-certified wood. Other markets occasionally mentioned include Indonesia, Australia, India and Central American. There were no requests from Africa, South America or the countries of Eastern Europe.

In response to the survey question: 'Please estimate by market the percent of customers demanding certified hardwood products.' the responses were extremely varied. For Northern Europe the requests for CHWP ranged from $<1 \%$ to $100 \%$ of the total customers purchasing U.S. hardwoods. In Southern Europe the range was 1-30\% with the average per cent of requests being $12 \%$. Chinese customers are requesting CHWP between 3-30\% of the time and some exporters noted that Chinese requests are increasing. A higher percentage of Japanese customers (11.5\%) request CHWP than do Canadian customers $(4.6 \%)$.

\section{ADEQUACY OF SUPPLY}

The question about adequacy of supply received mixed responses in spite of the fact that 29 of 33 said 'no' there is not an adequate supply. This paradox is illustrated by this response, "No. Even if there were a demand the supply could not meet it." Ambivalence 
is illustrated in the response, "More clients would probably request certification if they thought it was readily available." Large companies have a supply advantage as expressed by this exporter, "Yes, [the supply is adequate] because we have our own forests and they are all certified." Others say the supply is adequate because there is no demand. The responses are summarized in Figure 8 (page 50).

\section{IMPORTANCE RANKING}

The survey respondents were asked to rank 18 features of a lumber order in relative importance with an eco-label. (See Figure 9, page 50) First and foremost kiln drying was the most important feature of an order. Other concerns such as appearance, grade, reliability of supply, cleanness, reliable delivery, and packaging all held very similar rank just above friendly staff, cleanliness and custom features of an order. The presence of an ecolabel/certification was $18^{\text {th }}$ of the 19 features. As one exporter commented “..., if the customer is looking for certified lumber and has to have it, none of these are important." Another says, "No customer is willing to reduce quality specifications to receive 'certified'." Relative importance of factors in a lumber order depends on the level of commitment to the environment by the customer.

\section{WILLINGNESS TO PAY A PREMIUM}

As stated in Chapter 1 the bottom line in the success of certification systems is the customers' willingness to pay a premium to receive CHWP. Twenty of the 33 exporters stated that their customers will only pay less than $1 \%$. In fact, most of this group emphatically noted that customers were not willing to pay any premium. Ten exporters thought their customers would pay between $1 \%$ and 3\% CHWP. Only 3 companies had customers willing to pay more than three percent. (Figure 10, page 51) The general attitude is well represented in the following comments:

- "Customers are not willing to pay any premium... Our customers are not willing to pay any more money for certified wood nor do they care. Price is everything except for customers that are extremely environmentally conscious." 
- "Customers will not pay more to have certified lumber of any kind bottom line for most is price and quality..."

- "The customer rarely asks and as soon as they hear it costs more are not interested."

- "Some overseas customers like to specify certified stock but when we quote a higher cost they usually purchase non-certified stock at a lesser price."

- "More demand than supply, but not more business than we can supply, since most customers refuse to pay a premium."

- "Despite of what consumers tell us in mails or surveys we have found absolutely no willingness on the part of consumers to pay more for certified hardwoods."

- "No customer is willing to pay more for 'certified"."

- "Only about $1 \%$ asks for certified and will not pay any premium for certified wood unless forced to by final customer."

- "In general, most buyers are not willing to pay more for certified material. However, if it is required for a special assignment cost is not usually a major factor - they will buy from the most competitive supplier."

The consensus among these suppliers is that price and quality drive the market and consumers will not pay extra unless they see 'certification' as an added value.

\section{INTERNET INFLUENCE}

In obtaining the mailing addresses for this survey the NHLA web site became a valuable resource. Of the 265 companies initially contacted 145 (55\%) had a web site. Since this study is about certification, each web site was perused in an attempt to understand the respective company's position on environmental matters. Fifty-five of the 145 web sites (38\%) contained some statement regarding environmental values (Figure 11a, page 52). These statements ranged from evidence of full certification to statements of support for the principles of sustainable forestry. The exporters' responses were compared with the presence of a web site and a positive environmental statement to determine if positive 
environmental advertising would result in increased requests for CHWP. Of these 55 exporters with positive environmental statements only $7(13 \%)$ had requests for CHWP (Figure 11b, page 52). This does not seem to support the idea that advertising environmental values leads to more requests for environmentally friendly products. However, the numbers are small and these data were not the object of this study. 


\section{CHAPTER 5 DISCUSSION}

Forest certification began as a means of stopping the loss of tropical forests even though only 19\% of tropical timber reached the world's markets (Smouts 2002). Certification has failed to reduce tropical deforestation because the driving force in under-developed countries is poverty, subsistence agriculture and a huge dependence on wood for fuel and not over-harvesting for marketable timber. After the inception of forest certification in the early 1990's there were many predictions that certification would catch on world wide, provide a 'green' market and save forests. In 1995 Kiekens cautioned, in an editorial in Unasylva (the publication of the Food and Agricultural Organization of the United Nations), "Sustainable forest management can take place without timber certification. Conversely the extent to which certification can help to improve forest management remains unclear, while its economic costs may be significant. The illusion that certification can induce sustainable forest management at no cost, even on a moderate scale, must be dispelled." In fact, forest certification has become a big business with many competing organizations positioning themselves for market supremacy.

In the United States alone there are at least eight different certifying schemes. Some are recognized by FSC and some are not. Industry initiated systems such as SFI profess to be more scientific in that they are based on measurable criteria and indicators but the environmental NGO's will not accept them because they are from industry. The systems backed by environmentalists are not accepted by industry because they contain provisions that are inconsistent with well managed American forests, such as factors concerning indigenous people. Additionally, they are generally not based on criteria with measurable outcomes. Many certifying groups are trying to attain mutual recognition and acceptance world-wide thus assuring markets for their products.

The success of forest certification depends on consumer demand for environmentally friendly products. Surveys of individuals and households in the United States and Europe have predicted a strong 'green' market for producers of CWP. These surveys provided the respondent with hypothetical situations and asked for purchasing decisions related to 
their beliefs about the environment. Table 3 summarizes some of these reports showing an enthusiastic response to the idea of buying 'green'. Another study questioning people who had recently purchased a home showed a somewhat lower level of enthusiasm for spending extra for CWP (Grönroos \& Bowyer 1999). In nearly all surveys people thought the environment was important, but spending money on it was another matter. The exporters surveyed in this study express a different view than did the surveys of the 1990's. Consumers appear to be more interested in price and quality and are not willing to pay additional money for an invisible value. Unless the consumer sees and eco-label as an added value the certified wood product market will not grow.

Previous surveys of the attitudes of the producers and sellers of CWP are much fewer in number and revealed a much lower level of interest in purchasing or selling environmentally friendly products. The present study was undertaken to find out who outside the United States is asking for CHWP in an actual purchase situation and not a hypothetical survey setting. The very good response rate to this survey suggests a high level of interest in the question of certification by the hardwood exporters and their willingness to share their insights was valuable to the understanding of the problems facing these businesses and the attitudes in the market.

The surveyed U.S. hardwood exporters included a variety of types of businesses and diversity of experience. The large companies having their own tracts of forest land see the market for CHWP as an opportunity to further develop the niche markets that already exist such as in the UK and Europe. These companies can bear the cost of certification of their forests much more easily than can the small landowner. The large integrated companies using their own certified timber do not have an extra burden imposed by the necessity for 'chain-of-custody' documentation. One southern exporter admitted that they did not charge any more for certified products than that charged by companies handling non-certified northern hardwoods. Because the quality of their hardwoods was not quite as good as the northern timber the small added premium did not price them out of the market. 
On the other hand, many of the exporters resented the imposition of certification systems in the United States because owners of forest operations are required to follow Best Management Practices imposed by state law and they were believed to recognize the need to practice sustainable forestry without third party intervention. For the private forest owner - and over half of the nation's forests are privately owned (Table 2, page 41) - there is little opportunity to recoup the costs of certification nor is there incentive to undertake the process of certification. Without real incentive for undergoing the process of certification the landowner is unlikely to take that step.

Chain of custody documentation must proceed from forest to end product. For large integrated companies handling only certified timber this is not an issue. This also is not the reality for much of the hardwood timber industry. An owner of a large distribution yard in the southeastern U.S. related the problems of keeping stock separate as it progressed through their yard. His experience is identical to that reported earlier by Buckley and Ansell (2000). This southern company usually sells their small stock of certified lumber as part of a bigger order for non-certified lumber and absorbs the financial loss. He also related that several exporters in his area are now refusing to deal with certified timber because the chain of custody tracking is too costly and complicated.

A major problem in studying the actual flow of certified wood products internationally is lack of data. There are no customs regulations for tracking certified wood products. The FAO publishes data concerning all types of timber and wood product movement worldwide (Peck 2001 and FAO, 2003) but they have no information on the movement of certified wood products. Markets for CWP are difficult to quantitate for the same reason. The surveyed exporters have indicated that Europe, especially the United Kingdom, Germany and the Netherlands remain the principle end consumers of CHWP outside the United States. Japan and Canada also provide markets but to a lesser extent than does Europe.

The new market in the CHWP trade is China. In 1995 they were insignificant in terms of wood product imports or exports. By 1997 they had begun to import timber in much 
larger amounts though the export numbers did not rank in the top 20 countries for exports. The 2002 report of the Foreign Agricultural Service (FAS) of the U.S. Department of Agriculture lists China as the third largest importer of wood products world-wide and most of their imports are hardwoods. They import primary wood products such as logs, lumber and veneer and were the top importer of hardwood logs in 2002. In 1998 the Chinese imported $\$ 2.5$ million worth of hardwood logs and almost $\$ 15$ million in hardwood lumber. By 2002 those import values rose to $\$ 44,438,000$ in logs and $\$ 84,325,000$ in lumber. (FAS, 2003) (See Figure 12) The Chinese are described by Peck (2001) as in-transit processors. They import raw materials and export finished products to customers such as Home Depot and other stores dealing with CWP. In this survey China provided the third most requests for CHWP. As other home improvement and do-it-yourself stores market certified products the demand from in-transit processors such as China, India and Indonesia for CWP is apt to rise.

The Internet was an integral tool for this study. The Internet was born about 25 years ago out of an effort to connect the U.S. Department of Defense and various satellite and radio networks. Availability for commercial use began in 1993. Interest quickly increased and by 1996 the use was doubling each year. A survey by Vlosky and Gazo (1996) of members of the Forest Product Society found that the major Internet users at that time were universities followed by government. Websites as a tool for private companies was not even mentioned. In 1997 Vlosky and Fontenot showed that 28.3\% of the companies surveyed had a Web home page. By 2000 Pitis and Vlosky reported that $43.1 \%$ of respondents had established websites with links to other industry-related sites and that $81.7 \%$ use the Internet to conduct business, the most prevalent use being e-mail (94.1\%). They projected considerable growth in the next two years. Vlosky and Smith (2002) looked at eBusiness use in the hardwood lumber industry. They described owners of hardwood lumber businesses as slow to embrace change and adopt new ways of doing business. In a survey sent to all members of the NHLA they had an adjusted response rate of $12 \%$. Fifty-five percent of their respondents reported having a website. Half of these respondents said they used their websites primarily for promotion and advertising. 
The current survey of hardwood exporters did not focus on eBusiness as a part of the data gathering, but nonetheless found that $58.5 \%$ of the companies contacted had websites (Refer to Figures 11a \&11b). Part of the advertising on 55 of these sites was some form of statement of support for environmental concerns, but only seven of these companies had requests for CHWP. It is interesting to speculate on what role the positive environmental statements might have played with prospective customers. 


\section{CHAPTER 6 CONCLUSIONS AND RECOMMENDATIONS}

Since the inception of forest certification ten years ago there has been a slow but steady increase in certified forest acreage, but world-wide the certified forest area represents only about $2.5 \%$ of total forest area. The markets in general are niche markets with some emergence of home improvement and do-it-yourself stores marketing certified products. Europe remains the major consumer of certified products while China in the last five years has emerged as a major in-transit processor. China imports primary wood products and exports finished products. Therefore they are requesting CHWP when their end customer specifies certified products. Willingness to pay more for environmentally friendly products was found to be much more enthusiastic when the choices are hypothetical. In this survey of real purchasing characteristics there is almost no WTP a premium for CHWP.

There is much confusion and resentment caused by the myriad of certification schemes. For certification to become more accepted by forest owners and industry there must be mutual recognition and reciprocity of certifying systems. These systems also need to be scientifically based so that outcome measurements are possible. Very few land owners have incentives to certify their forests. The promised markets are not developing as rapidly as projected by the environmental groups who initiated the concept of certification.

Better data are necessary to evaluate the impact of CWP on the market. With the majority of exporting hardwood companies doing business on the Internet it should be possible to better track the certified wood products. Import/export data are readily available for wood products in general through the data of FAO and FAS.

For consumers to be willing to pay a premium for CHWP they must see the eco-label as an added value otherwise one piece of wood looks just like the next. If market pressure lessens will certification continue to exist? 


\section{BIBLIOGRAPHY}

Anonymous, 2003. "Seeing the Forests and the Trees (and Everything Else)." Forest Focus, (Spring) 2-6, MeadWestvaco/Forestry Division

Berg, S. and R. Olszewski, 1995. "Certification and Labeling” Journal of Forestry, 93 (4): 30-32.

Bigsby, H. and L.K. Ozanne, 2002. "The Purchase Decision: Consumers and Environmentally Certified Wood Products.” Forest Products Journal 52 (7/8): 100-105.

Brooks, David J. 1993. U.S. Forests in a global context. USDA Forest Service, Rocky Mountain Forest and Range Experimental Station, General Technical Report RM-228

Buckley and Ansell, 2000 "Sourcing US Hardwood Materials for French Furniture Manufacture: A 'Chain of Custody' Case Study." Journal of the Institute of Wood Science: 15(4) (from www.sustainableforestry.com)

Cabarle, B., R.J.Hrubes, C. Elliot and T. Synnott, 1995. "Certification and Accreditation: The Need for Credible Claims.” Journal of Forestry, 93 (4): 12-16.

Carter, D.R. and F.D. Merry, 1998. "The Nature and Status of Certification in the United States.” Forest Products Journal 48(2): 2332.

Dillman, Don A., 2000. Mail and Internet Surveys: The tailored design method. Second edition. John Wiley \& Sons, Inc., New York.

Floyd, D.W., S.L. VonHof and H.E. Seyfang, 2001. "Forest Sustainability: A discussion Guide for Professional Resource Managers.” Journal of Forestry, 99(2): 8-16.

Food and Agriculture Organization of the United Nations, 2002 report. www.fao.org/forestry

Foreign Agricultural Service, 2003. "Forest Products - U.S. Exports Trade Data and Presentations." U.S. Department of Agriculture, www.fas.usda.gov

Grönroos, J.C.M. and J.L. Bowyer, 1999. “Assessment of the Market Potential for Environmentally Certified Wood Products in New Home in Minneapolis/St. Paul and Chicago.” Forest Product Journal 49(6):28-34.

Hendricks, R.L. 2003. 'International dialogue on sustainable forest management.' Journal of Forestry 101(5): 46-49

Kiekens, J.P., 1995. “Timber Certification: a critique.” Unasylva 183 vol. 46: 27-28. 
Lober, D.J. and M.D. Eisen, 1995. "The Greening of Retailing: Certification and the Home Improvement Industry." Journal of Forestry, 93(4): 38-41.

Lyke, J. and D.J. Brooks, 1995. "World Supply and Demand for Forest Products." Journal of Forestry, 93(4): 22-26.

Mater, J. 1995. "Certified Forest Products: Building Tomorrow’s Market Today." Journal of Forestry, 93(4): 36-37.

McNulty, J.W. and J. H. Cashwell, 1995. "The Land Managers Perspective.” Journal of Forestry, 93(4):38-41.

Murray, B.C. and R.C. Alt, 2001. "Estimating price compensation requirements for ecocertified forestry.” Ecological Economics 36: 149-163.

North American Hardwood Export Buyers Guide, 2001, Produced by the National Hardwood Lumber Association. Memphis, Tennessee, USA

Ozanne L.K. and Paul M. Smith, 1998. "Segmenting the Market for Environmentally Certified Wood Products.” Forest Science 44(3): 379-389.

Ozanne, L.K. and R.P. Vlosky, 1997. "Willingness to Pay for Environmentally Certified Wood Products: A Consumer Prospective.” Forest Products Journal 47(6): 39-48.

Oliver, C.D. 2003. "Sustainable Forestry: What is it? How do we achieve it?" Journal of Forestry 101(50: 8-14.

Oliver, Rupert, 2002. “The Missing Link” On web site of American Hardwood Export Council, www.sustainableforestry.com

Peck, T. 2001. The International Timber Trade. Woodhead Publishing Limited, Cambridge England.

Peck, T. 2001. “The International Timber Trade” Forest Products Journal 52 (9) 10-19.

Pearl, D. and D. Fairley, 1985. "Testing for the potential for non-response bias in sample surveys.” Public Opinion Quarterly 49:553-560.

Pitis, O.T. and R.P. Vlosky, 2000. "Web Presence of U.S. Primary Wood Products Exporters" Forest Products Journal 50(7/8): 55-58

Rametsteiner, E. 1999. "The Attitude of European consumers towards forests and forestry." Unasylva 196 vol. 50: 42-48.

Rickenbach, M.G., 2002. "Forest Certification of Small Ownerships: Some Practical Challenges." Journal of Forestry, 100 (9): 43-47. 
Ruddell, S. and J.A. Stevens. 1998. "The adoption of ISO 9000, ISO 14001, and the demand for certified wood products in the business and institutional furniture industry. Forest Products Journal 48(3):19-26

Salant, Pricilla and Don A. Dillman. 1994. How to Conduct Your Own Survey, John Wiley \& Sons, Inc., New York.

Smith, W.B., J.S. Vissage, J.S. Darr, D.R. \& R.M. Sheffield, 2002. Forest Resources of the United States, 1997. General Technical Report NC-222, USDA, Forest Service, North Central Research Station.

Smouts, M. C. 2003. "Forest Certification and Timber labeling: the hidden agenda" www.isanet.org/noarchive/smouts.html

Stevens, J., M. Ahmad and S. Ruddell, 1998. "Forest Products Certification: A Survey of Manufacturers.” Forest Products Journal 48(6) 43-49.

Veisten, K. 2002. "Potential Demand for Certified Wood Products in the United Kingdom and Norway." Forest Science 48(4): 767-778.

Vlosky, R.P. and R. Fontenot, 1997. The Internet and the forest products industry: Current Status and projected trends. Forest Products Journal 47(11/12): 33-40

Vlosky, R.P. and R. Gazo, 1996. "The Internet and The Forest Products Community: The Role of the Forest Products Society.” Forest Products Journal 46(5): 19-25

Vlosky, R.P. and L.K. Ozanne, 1995. "Chain of Custody vital to certification process" Wood Technology 50(March/April) 35-36.

and 1997. "Forest Products Certification: The Business

Customer Perspective" Wood and Fiber Science, 29(2): 195-208

Vlosky, R.P. and T.M. Smith, 2003. "eBusiness in the U.S. hardwood lumber industry." Forest Products Journal 53(5): 21-29 


\section{APPENDIX A}

SURVEY INSTRUMENT 
Concern over the health of the environment along with maintaining a continuing source of wood products has led to several certification schemes to assure sustainable forestry. This survey is attempting to assess global awareness and acceptance of certification/ecolabeling of wood products by hardwood buyers on the international hardwood market.

Please complete the following questions to allow the results of this study to be representative of the market experience. Thank you.

\author{
Division of Forestry \\ West Virginia University \\ P.O. Box 6125 \\ Morgantown, WV 26505-6125
}

1. Are your international customers asking for certified hardwood products?

Yes your time)

No (If 'no' please return the survey in the enclosed envelop. Thank you for

2. Which markets are asking for certified products (check all that apply)?

Canada

Northern Europe (UK, France, Scandinavia, Germany, Holland, Belgium...)

Southern Europe (Italy, Spain, Greece, Turkey...)

Eastern Europe (Former eastern block countries and Russia)

Pan - Pacific Countries (please specify which countries)

Japan

Philippines

New Zealand

Australia

Indonesia

China

India

Africa

Central America and Mexico

South America

3. Are customers expressing a preference for type of certification (i.e. Forest Stewardship Council (FSC), SmartWood, Scientific Certification Systems (SCS), Sustainable Forest Initiative (SFI), etc.)?

Yes

If yes which certification system is most often requested?) FSC (SmartWood or SCS)

SFI

Other (please specify)

No 
4. Which geographic markets as listed above specify FSC? (List all that apply)

5. Which areas as listed above specify SFI? (List all that apply)

6. Do you as exporters have a sufficient supply of certified hardwood material to meet demands?

$\underset{\text { Yes }}{\longrightarrow}$

7. Do your customers demand products that bear a recognizable eco-label (i.e. FSC stamp)?

$\underset{\text { Yes }}{\text { No }}$

8. Please estimate by market the percent of customers demanding certified hardwood products.

Canada

Northern Europe (UK, France, Scandinavia, Germany, Holland, Belgium) Southern Europe (Italy, Spain, Greece, Turkey...)

Eastern Europe (Former eastern block countries and Russia)

Pan - Pacific Countries (please specify which countries) Japan

Philippines

New Zealand

Australia Indonesia

\begin{tabular}{ll} 
China \\
\hline India \\
Africa \\
Central America and Mexico \\
South America
\end{tabular}

9. In your experience, how much of a premium are international customers willing to pay for certified hardwood products?

Less than $1 \%$

$1-3 \%$

$3-5 \%$

More than 5\% 
10. How does certification compare in importance to other product or service attributes such as delivery time, price, quality, availability, etc.? (Please circle the number that best describes the average importance of each attribute, based upon your experience, to your international customers.)

$\begin{array}{ll}\text { NOT } & \text { VERY } \\ \text { IMPORTANT } & \text { IMPORTANT }\end{array}$

$\begin{array}{llllll}\text { Neat, attractive packaging/wrapping } & \mathbf{1} & \mathbf{2} & \mathbf{3} & \mathbf{4} & \mathbf{5} \\ \text { Lumber cut to precision length } & \mathbf{1} & \mathbf{2} & \mathbf{3} & \mathbf{4} & \mathbf{5} \\ \text { Ability to provide surfaced lumber } & \mathbf{1} & \mathbf{2} & \mathbf{3} & \mathbf{4} & \mathbf{5} \\ \text { Ability to fill large orders } & \mathbf{1} & \mathbf{2} & \mathbf{3} & \mathbf{4} & \mathbf{5} \\ \text { Ability to fill small orders } & \mathbf{1} & \mathbf{2} & \mathbf{3} & \mathbf{4} & \mathbf{5} \\ \text { Ability to fill customized or } \quad & & & & \\ \quad \text { unusual requests } & \mathbf{1} & \mathbf{2} & \mathbf{3} & \mathbf{4} & \mathbf{5} \\ \text { Kiln dried lumber } & \mathbf{1} & \mathbf{2} & \mathbf{3} & \mathbf{4} & \mathbf{5} \\ \text { Appearance/color of lumber } & \mathbf{1} & \mathbf{2} & \mathbf{3} & \mathbf{4} & \mathbf{5} \\ \text { Product is always within grade } & \mathbf{1} & \mathbf{2} & \mathbf{3} & \mathbf{4} & \mathbf{5} \\ \text { Ability to provide metric sizes } & \mathbf{1} & \mathbf{2} & \mathbf{3} & \mathbf{4} & \mathbf{5} \\ \text { Friendliness/helpfulness of sales staff } & \mathbf{1} & \mathbf{2} & \mathbf{3} & \mathbf{4} & \mathbf{5} \\ \text { Reliability of supply } & \mathbf{1} & \mathbf{2} & \mathbf{3} & \mathbf{4} & \mathbf{5} \\ \text { Ability to deliver on time } & \mathbf{1} & \mathbf{2} & \mathbf{3} & \mathbf{4} & \mathbf{5} \\ \text { Competitive pricing } & \mathbf{1} & \mathbf{2} & \mathbf{3} & \mathbf{4} & \mathbf{5} \\ \text { Available credit at reasonable terms } & \mathbf{1} & \mathbf{2} & \mathbf{3} & \mathbf{4} & \mathbf{5} \\ \text { Presence of supplier's trademark/logo } & \mathbf{1} & \mathbf{2} & \mathbf{3} & \mathbf{4} & \mathbf{5} \\ \text { Lumber straightness } & \mathbf{1} & \mathbf{2} & \mathbf{3} & \mathbf{4} & \mathbf{5} \\ \text { Lumber cleanliness } & \mathbf{1} & \mathbf{2} & \mathbf{3} & \mathbf{4} & \mathbf{5} \\ \text { Any environmental certification } & \mathbf{1} & \mathbf{2} & \mathbf{3} & \mathbf{4} & \mathbf{5}\end{array}$

Thank you for completing this survey. Please return in the enclosed envelope to: Ellen Hrabovsky

West Virginia University

P.O. Box 6125

Morgantown, WV 26506-6125

If you would like an electronic copy of these results please include your e-mail address

Comments: 
APPENDIX B

\section{LETTER OF INTRODUCTION}

TO

U.S. HARDWOOD EXPORTERS 
June 15, 2002

\section{Dear Hardwood Exporter:}

We are seeking your help in assessing the demand for certified U.S. hardwoods on international markets. We in the Wood Industries program of the West Virginia University Division of Forestry are surveying U.S. hardwood exporters to evaluate the market for certified hardwoods. In addition, we are attempting to compare the acceptance of various certification schemes by international buyers in export markets. We expect the results of this survey to be useful to American producers and exporters in better satisfying the expectations of foreign customers.

Will you please complete the enclosed questionnaire and return it at your earliest convenience? Although your participation is voluntary and anonymous, your response is very important in order to obtain valid and accurate conclusions for the study. You do not have to answer all of the questions.

The number on the return envelop is simply for recording purposes and cannot be used to identify the respondent. This research is being conducted to fulfill the requirements for a Master of Science in Forestry. When you have completed the survey please return it in the enclosed envelop to:

\section{Ellen Hrabovsky \\ West Virginia University}

P.O. Box 6125

Morgantown, WV 26506-6125

In the meantime, should you have any questions please do not hesitate to contact me or Dr. James Armstrong at the above address. Thank you in advance for your assistance with this study.

Sincerely, Ellen Hrabovsky, Graduate Student, Wood Industries 


\section{APPENDIX C}

\section{FOLLOW UP LETTER}


August 28, 2002

\section{Dear Hardwood Exporter:}

This summer we sent you a survey designed to evaluate the demand by your international customers for certified lumber and other forest products. It is very easy to set such a mailing aside and forget it.

It is important for the accuracy of this research that we receive your voluntary reply if you can possibly take the time to respond.

Enclosed are the original cover letter explaining this project, the survey, and a postage paid return envelop. We appreciate your assistance in trying to determine the international demand for certification of lumber.

Sincerely,

Ellen E. Hrabovsky

Graduate Student 


\title{
APPENDIX D
}

\author{
TABLES \\ AND \\ FIGURES
}


Table 1

TOTAL AND CERTIFIED FOREST ACRES GLOBAL AND UNITED STATES

\begin{tabular}{|l|l|l|l|}
\hline LOCATION & $\begin{array}{l}\text { TOTAL FOREST } \\
\text { (acres) }\end{array}$ & $\begin{array}{l}\text { CERTIFIED } \\
\text { (acres) }\end{array}$ & $\begin{array}{l}\text { CERTIFICATION } \\
\text { SYSTEM (acres) }\end{array}$ \\
\hline GLOBAL & 10 billion & 250 million & $\begin{array}{l}\text { PEFC }=109 \text { million } \\
\text { FSC }=79 \text { million }\end{array}$ \\
\hline UNITED STATES & $\begin{array}{l}765 \text { million forested } \\
510=\text { timberland }\end{array}$ & 109 million & $\begin{array}{l}\text { SFI }=77 \text { million } \\
\text { Tree Farm }=26 \text { million } \\
\text { FSC }=6 \text { million }\end{array}$ \\
\hline & & & $\begin{array}{l}\text { Sources: Brooks } 1997 \\
\text { Smith 2002 }\end{array}$ \\
\hline
\end{tabular}




\section{TABLE 2 TIMBERLAND OWNERSHIP IN THE U.S.}

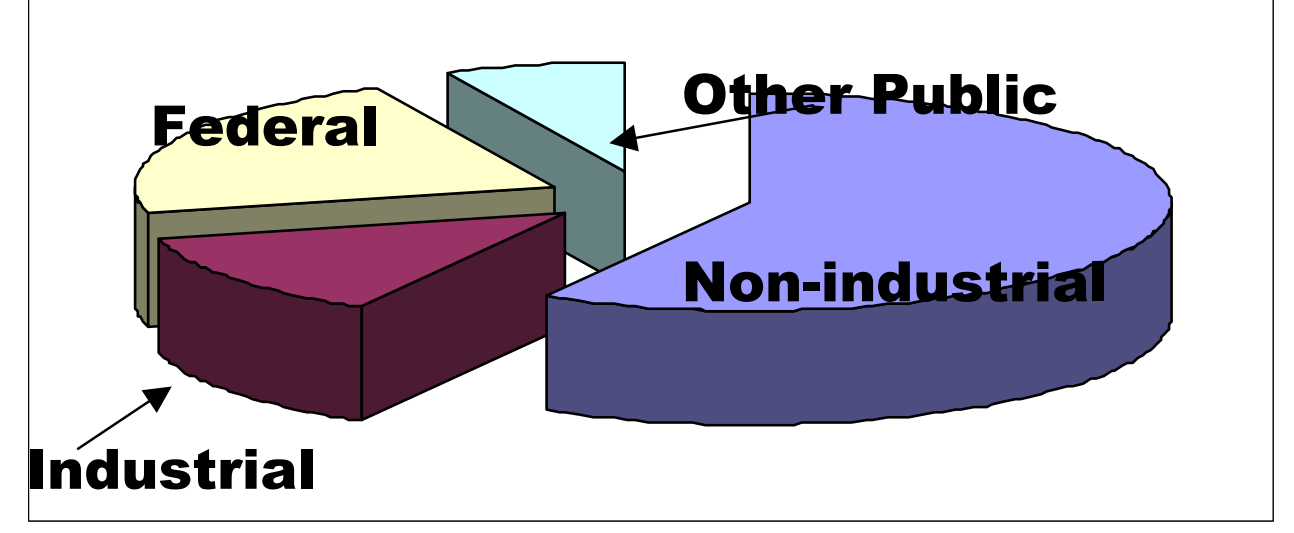

\begin{tabular}{|l|c|c|}
\hline \multicolumn{1}{|c|}{ OWNER } & PERCENT & ACRES (millions) \\
\hline Public & 29 & 145 \\
\hline Federal & 22 & 110 \\
\hline Other & 7 & 35 \\
\hline Non-Industrial Private & 58 & 295 \\
\hline Industrial & 13 & 67.5 \\
\hline
\end{tabular}




\section{Table 3. Willingness to pay estimates from cited surveys}

\begin{tabular}{|c|c|c|c|}
\hline \multirow[t]{2}{*}{ COUNTRY } & WILLINGNESS & TO PAY & REFERENCE \\
\hline & $\%$ of Population & Amount of Premium & \\
\hline \multirow{2}{*}{$\begin{array}{l}\text { United States } \\
\text { United States }\end{array}$} & 68 & $5-10 \%$ & Lober \& Eisen 1995 \\
\hline & 67 & $\begin{array}{c}4.418 .7 \% \\
\text { (based on value of } \\
\text { product) }\end{array}$ & Ozanne \& Vlosky 1997 \\
\hline United States & $24-36$ & $\begin{array}{l}\$ 2500 \text { extra on new home } \\
\text { construction }\end{array}$ & Grönroos \& Bowyer 1999 \\
\hline United Kingdom & $67 \%$ & $\leq 13.6 \%$ & Ozanne \& Vlosky 1997 \\
\hline United Kingdom & 39 & $<5 \%$ & Veisten 2002 \\
\hline Germany & 50 & $5 \%$ & Ozanne \& Vlosky 1997 \\
\hline Norway & 32 & $<5 \%$ & Veisten 2002 \\
\hline $\begin{array}{l}\text { European Union } \\
\text { Countries }\end{array}$ & 50 & $5.6-9.6 \%$ & Rametsteiner 1999 \\
\hline
\end{tabular}



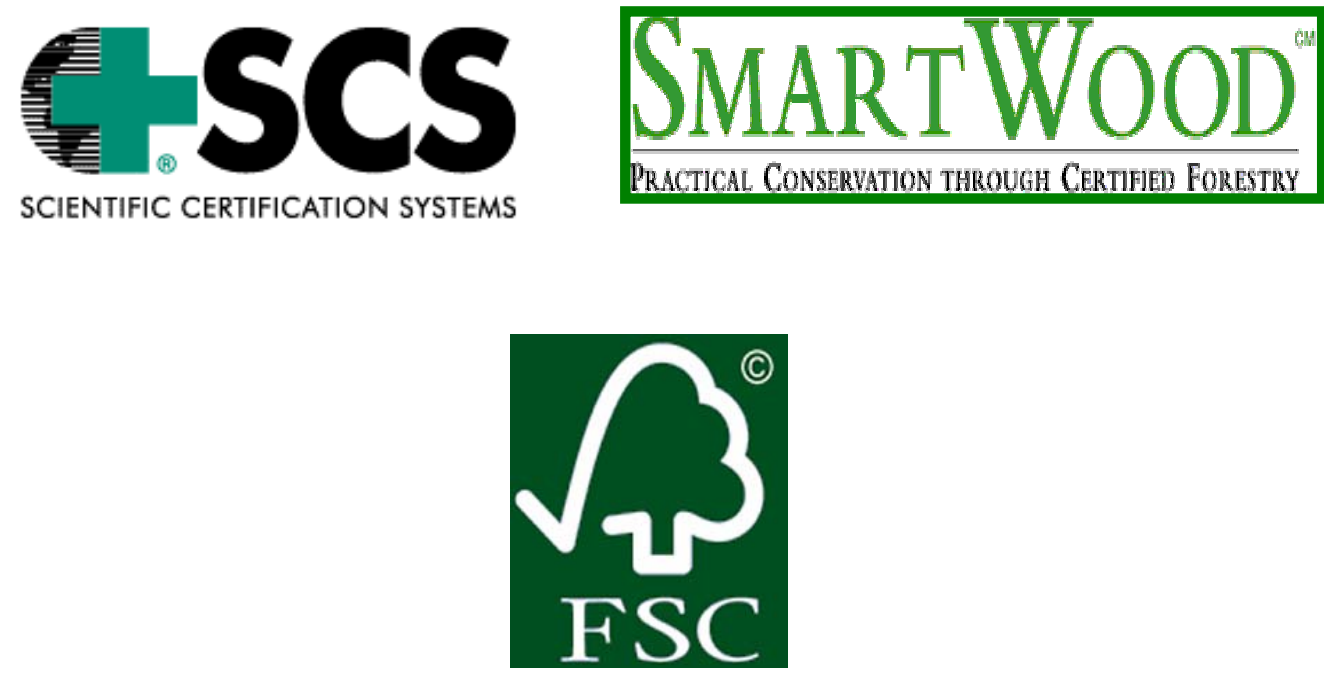

Figure 1. The above are the ecolabels of the third party certifiers Smartwood and Scientific Certification Systems. They function under the umbrella of the Forest Stewardship Council.
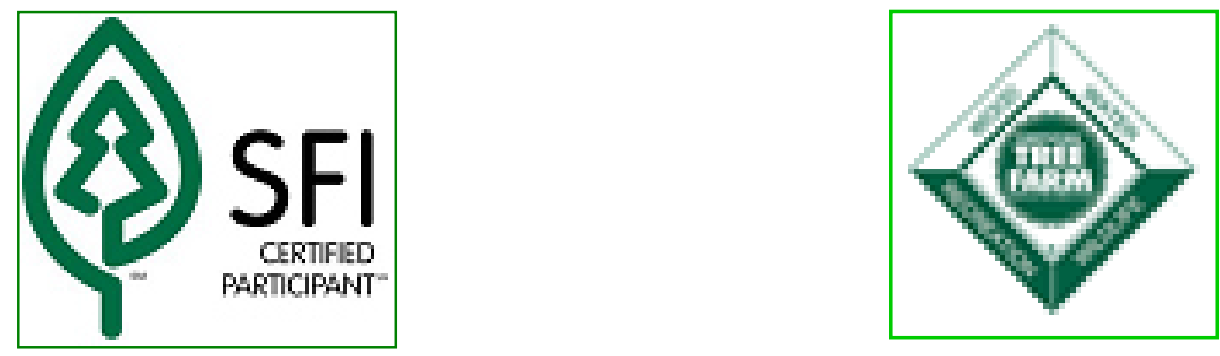

Figure 2. On the left is the ecolabel for the Sustainable Forestry Initiative developed by the American Forest and Paper Association. SFI compliance is a condition of membership in the AF\&PA. On the right is the ecolabel for the American Tree Farm System, the oldest of the certifying systems targeting private individual tree farms. 


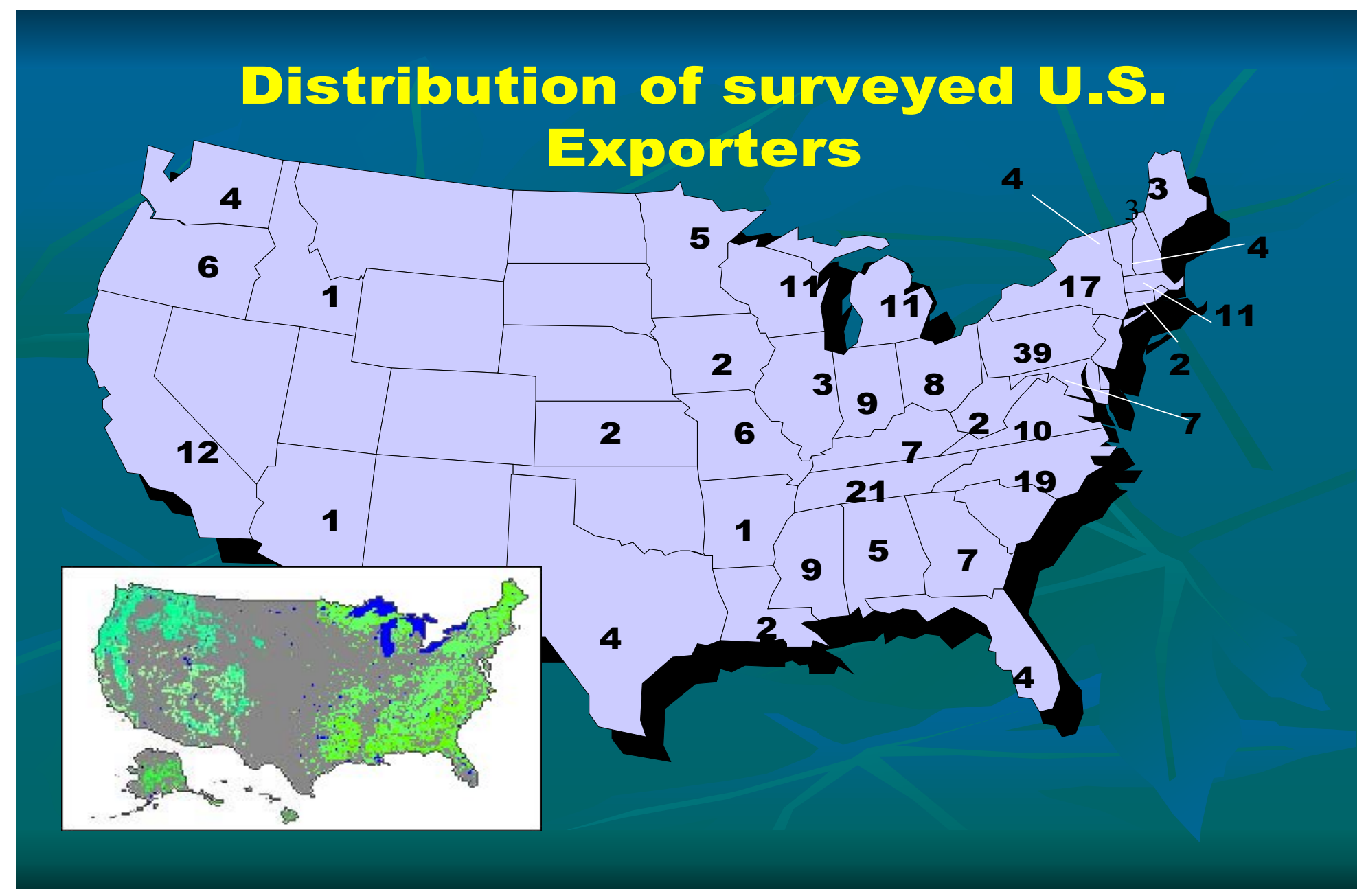

Figure 3. The national distribution of hardwood exporters contacted in this survey. The distribution coincides with the distribution of hardwood forests in the United States. (See insert-bright green $=$ hardwood forest.) 


\section{SURVEY RESPONSE}

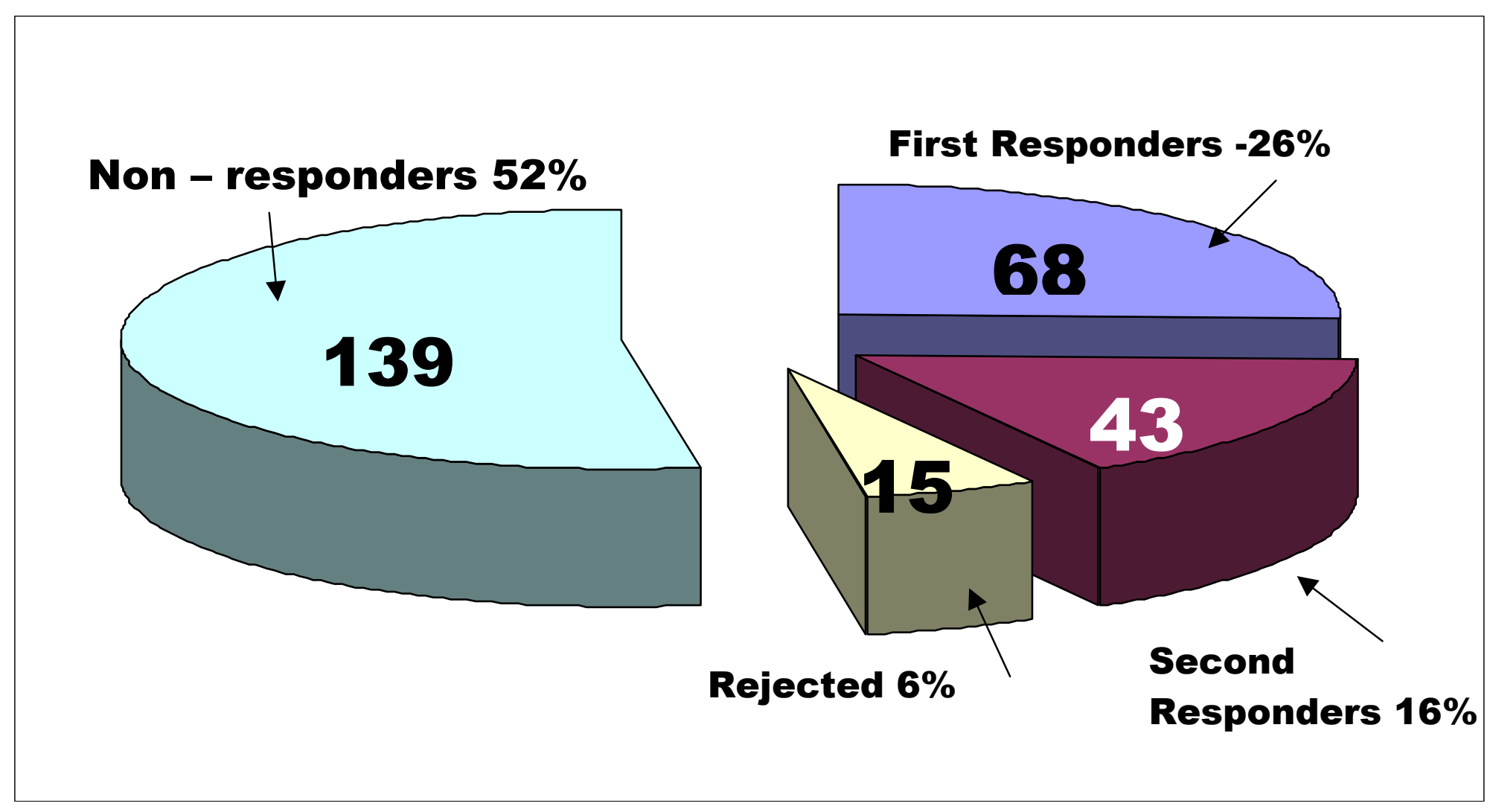

Figure 4. The response rate of the survey sent to hardwood exporters is $42 \%$. Of the initial 265 surveys mailed, 15 were returned as undeliverable (rejected), 68 companies responded to the first mailing and 43 to the second mailing. There were 139 non-responders. 


\section{Non-response bias}

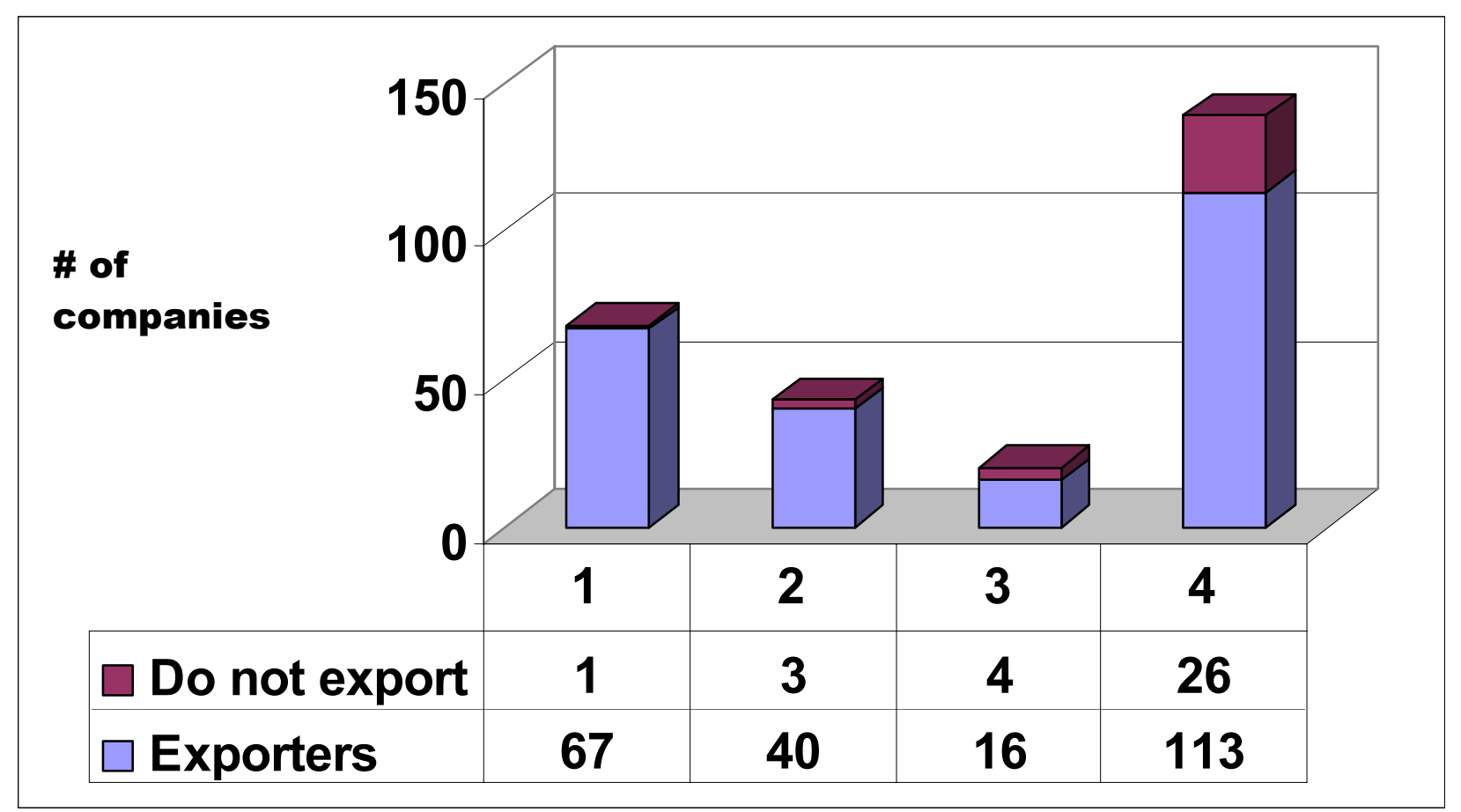

Figure 5. The numbers of companies that do not export increase from only one in the group of first responders (1) to 3 in the second responder (2) group. A sample of non-responders contacted by telephone (3) found 4/20 companies that did not export. Projecting that percentage to the entire non-response group (4) yields a projected 26 companies in the non-response group that do not export. There is a bias in the non-response group toward not exporting. 


\section{Companies with requests for CHWP}

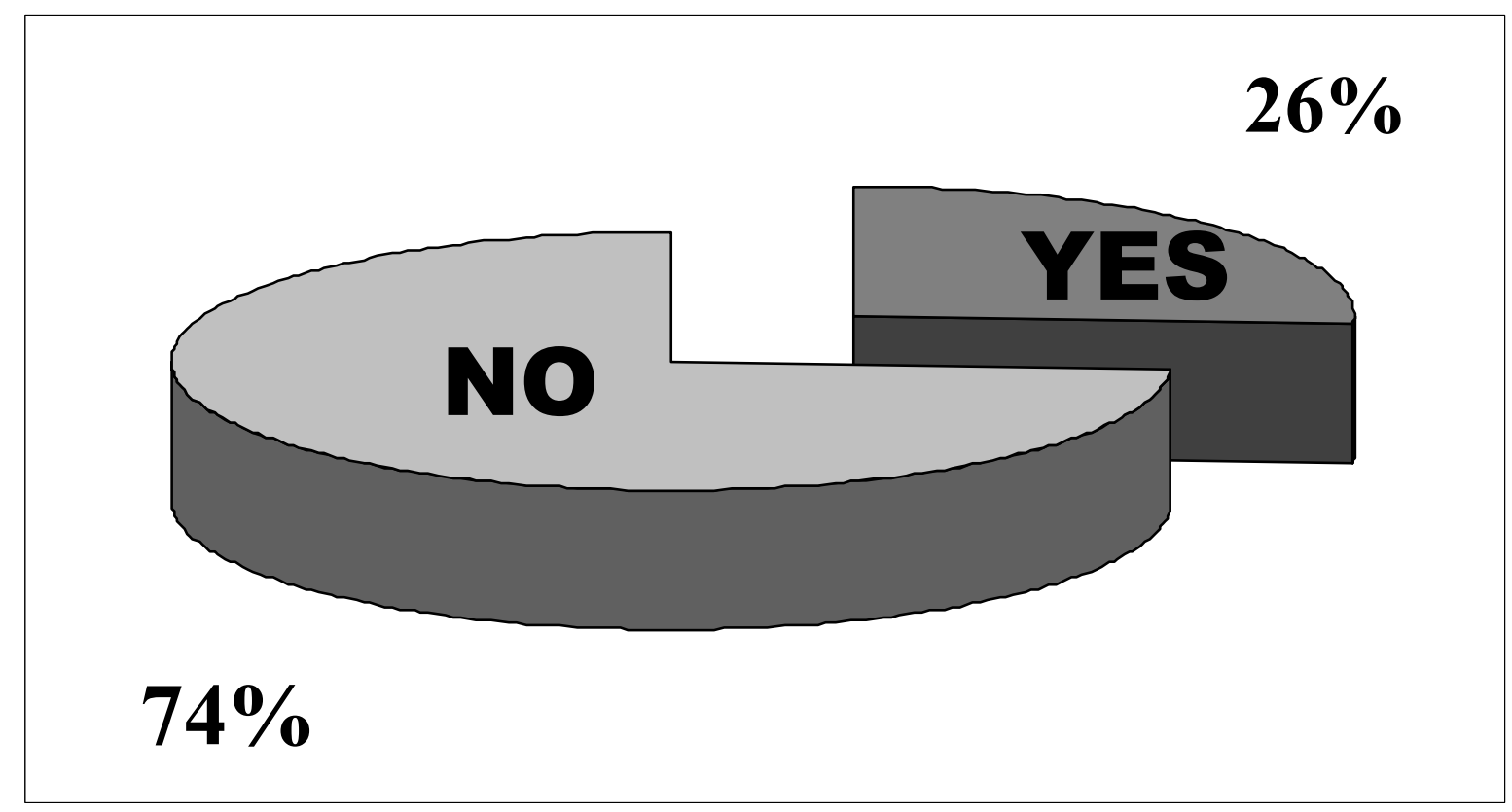

Figure 6. Twenty six percent of exporting companies receive requests $f$ or certified hardwood products. These numbers include mail and phone contacts. 


\section{Markets for Certified Hardwood Products}

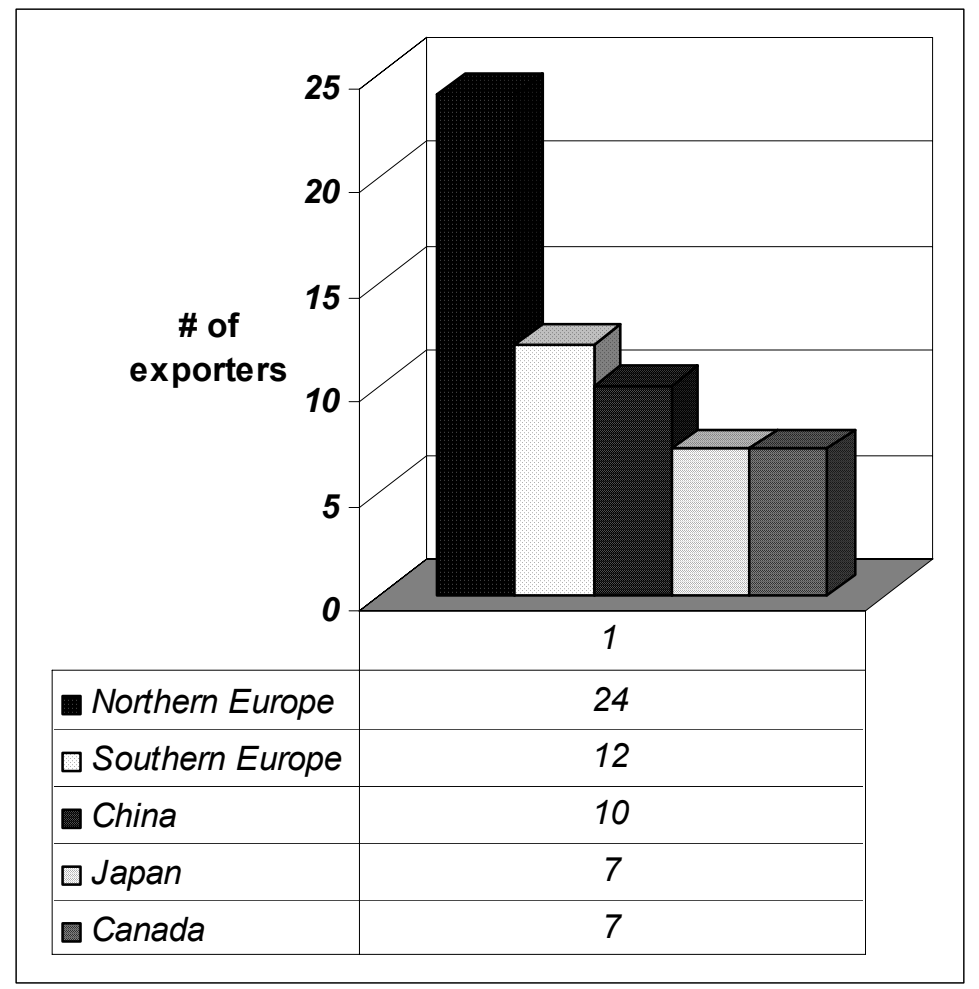

Figure 7. This bar graph illustrates the markets that are requesting CHWP from 30 U.S. hardwood exporters. Eighty per cent are in Northern Europe and most of these requests are from the UK, Germany and the Netherlands. China $(34 \%)$ is a new and growing market. 


\section{Supply, Certification Scheme and Eco-label}

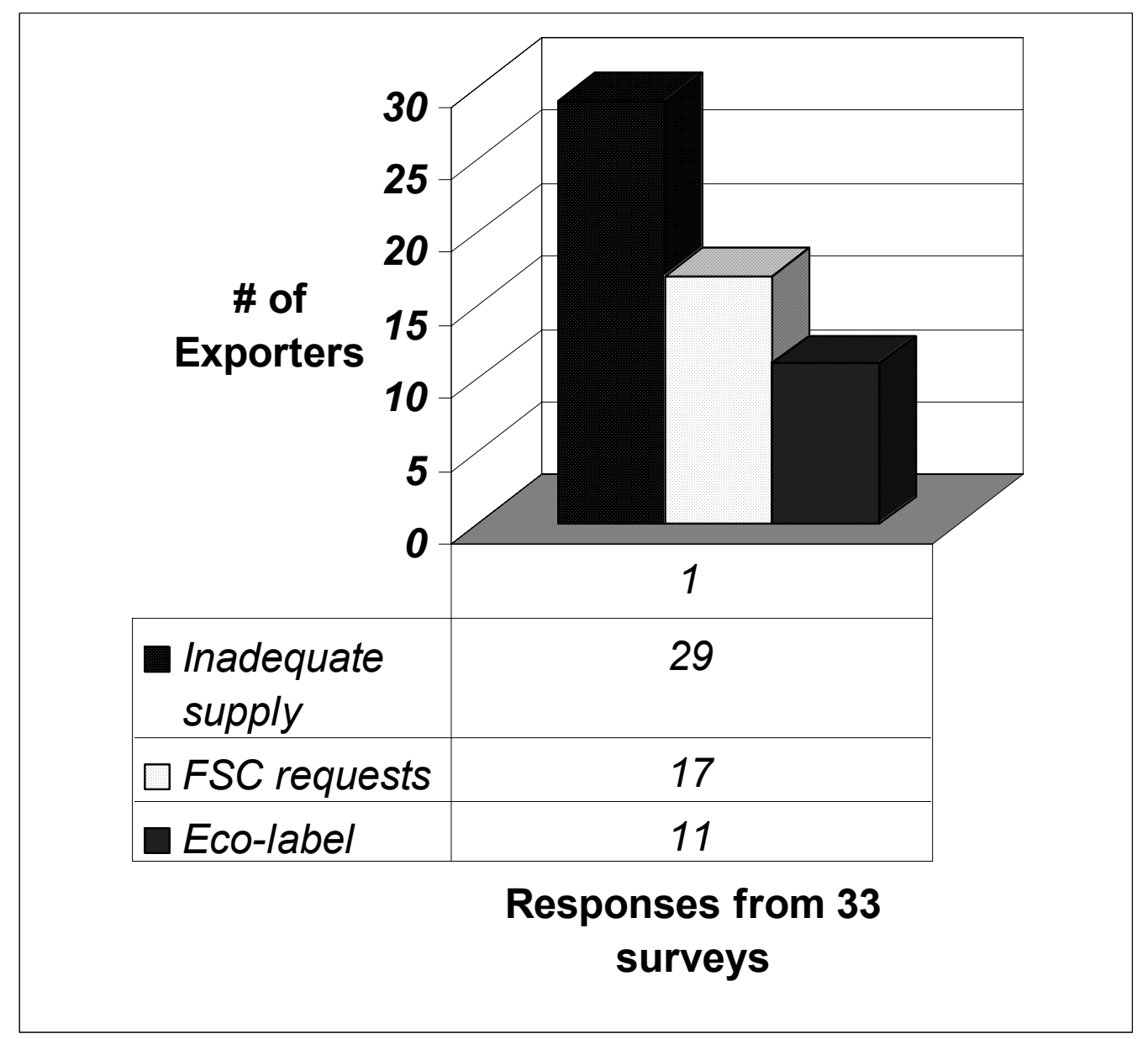

Figure 8. Responses from exporters receiving requests for CHWP concerning 1) adequacy of supply of certified lumber, 2) certification schemes requested (FSC only) and 3) the number of companies receiving requests for a visible eco-label. 


\section{Importance ranking of lumber orders}

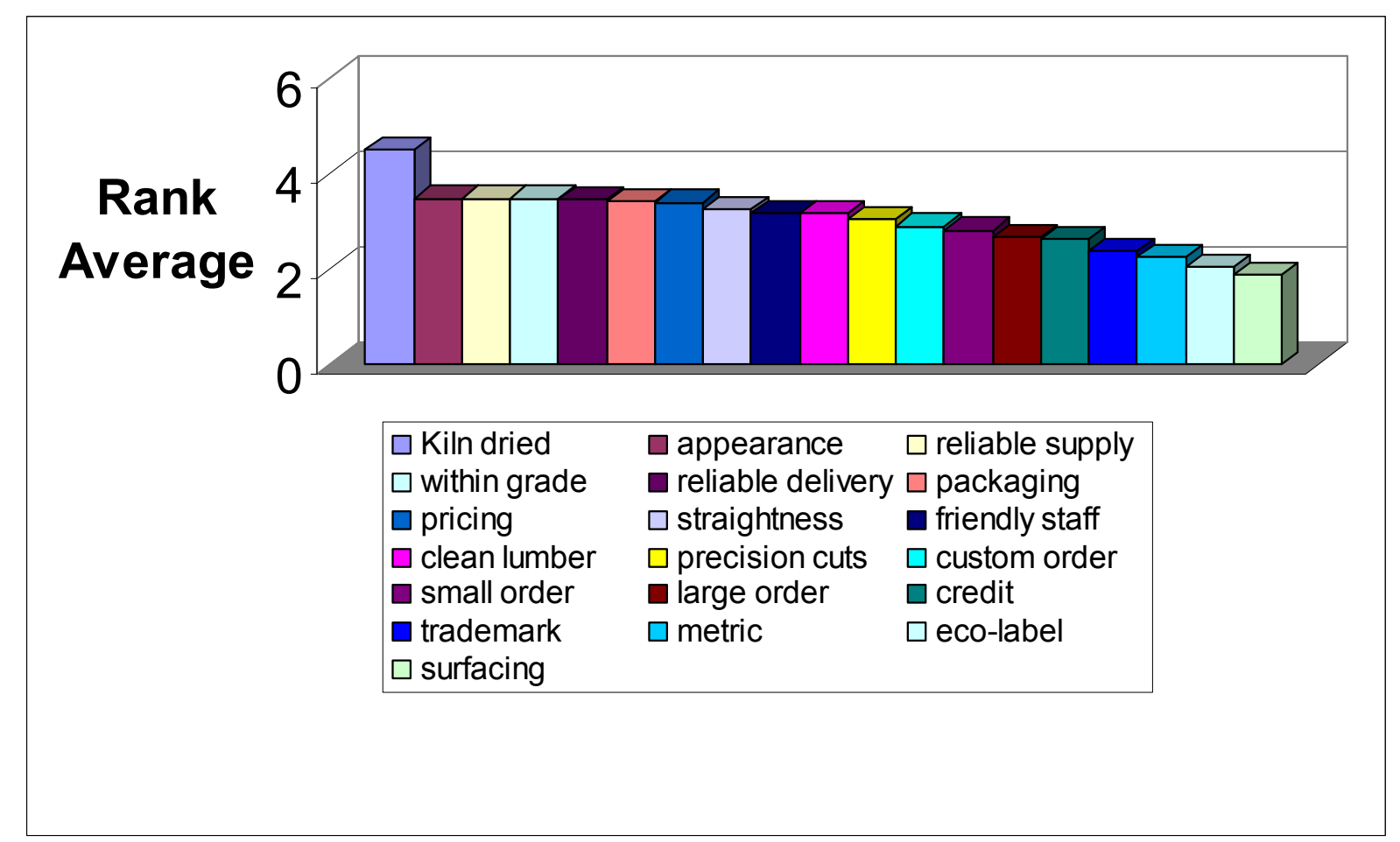

Figure 9. The rank ordering of important features of a lumber product order as judged by the U.S. exporter is shown in this bar graph. The eco-label isles important than all but one other feature and that is surfacing of the boards. 


\section{Willingness to pay a premium}

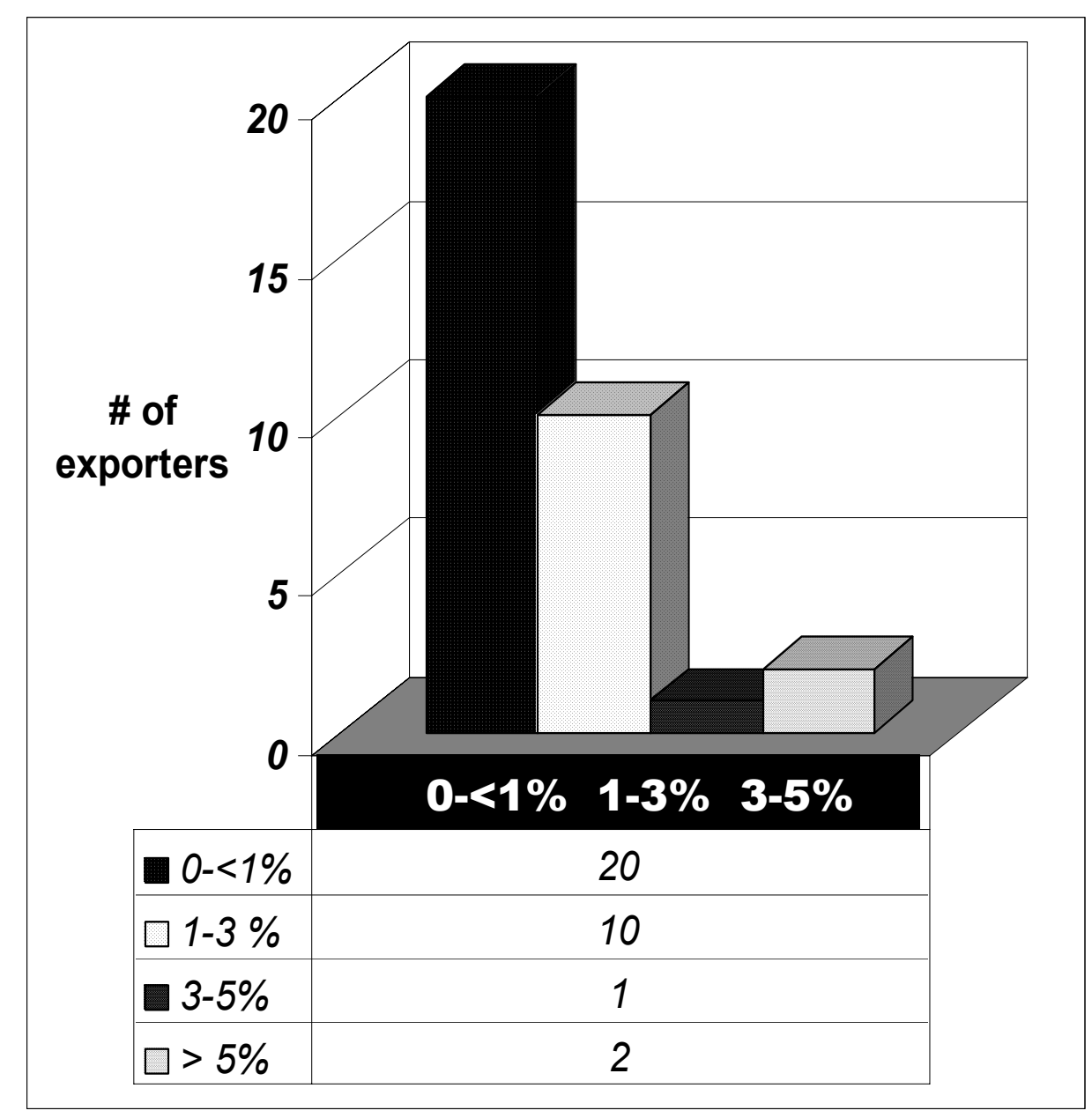

Figure 10. Willingness to pay a premium for certified wood products is illustrated here. Twenty of 33 exporters report that their customer generally will not pay any premium. Less than $1 / 3$ will pay a small premium and only 3 report customers who will pay more than $3 \%$. 


\section{Companies with web sites}

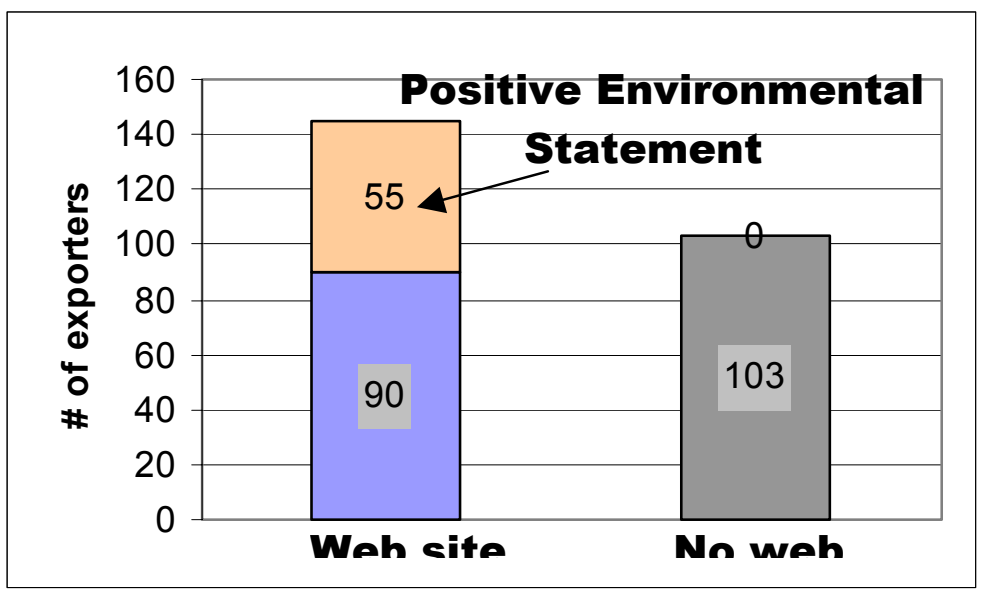

Figure 11a. Fifty eight percent (145) of exporters contacted had web sites, and of those with web sites $55(38.6 \%)$ had a positive environmental statement consisting of certification or support of sustainable forestry.

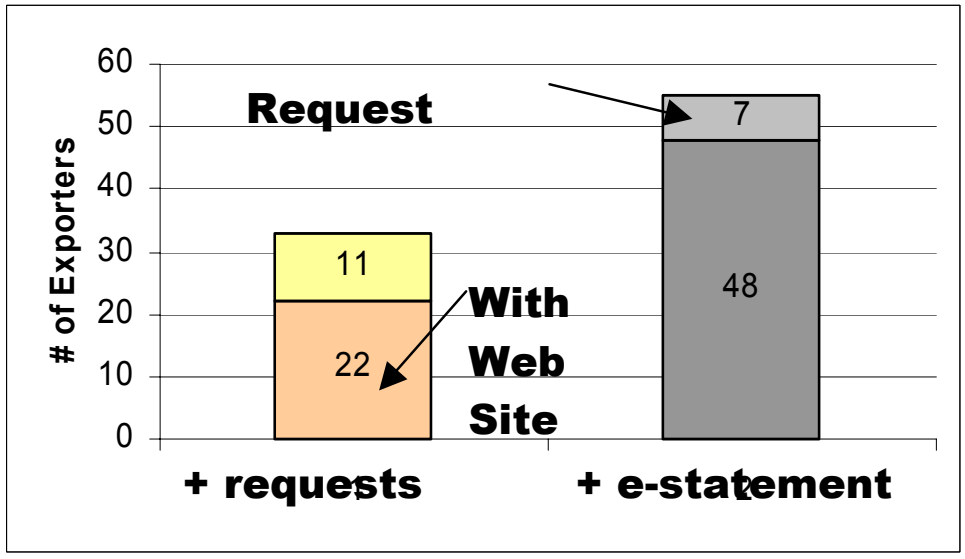

Figure 11b. Twenty-two of the 33 exporters having requests for CHWP have web sites. Of the 55 exporters with positive environmental statements only seven received requests for CHWP. 


\section{Hardwood Imports by Peoples Republic of China}

\section{8-2002}

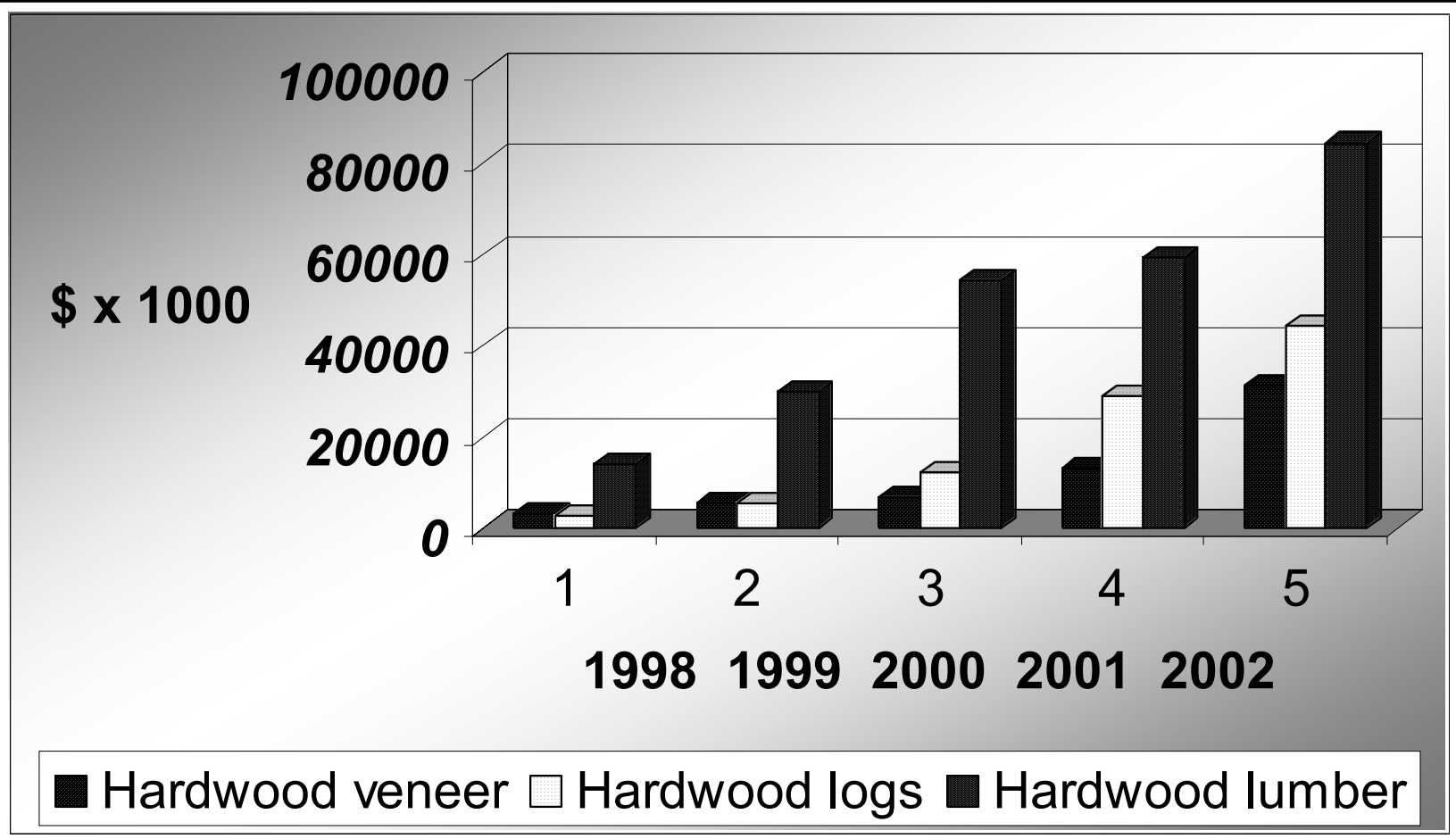

Figure 12. Data from the Foreign Agricultural Service of the USDA demonstrates the rapid increase in Chinese hardwood imports. As in-transit processors they import primary hardwood material and export finished products. They have developed an enormous furniture industry. (FAS 2003) 


\section{APPENDIX E}

\section{CURRICULUM VITAE}




\section{CURRICULUM VITAE}

\section{Ellen E. Hrabovsky, MD}

DATE OF BIRTH

MARITAL STATUS

ADDRESS

E-MAIL

EDUCATION

High School -

1957-1961

St. Bernard Academy

Nashville, TN

Valedictorian
College -

1961-1965 George Peabody College for Teachers Nashville, TN

Bachelor of Science Biology with

Medical School -

1965-1969 Honors June, 1965

Vanderbilt University,
November 21, 1943

Lansing, Michigan

Single

975 Tyrone Road

Morgantown, WV 26508-2971

(304) 296-1887

ellen1121@juno.com

Nashville, TN

Doctor of Medicine

MD June,1969

Graduate School -

1986-1988 The Ohio State University, Columbus, $\mathrm{OH}$

Department of Physiology,

No degree obtained

2000 -2003 Master of Science in Forestry

(Wood Science, August, 2003)

West Virginia University 
POSTGRADUATE SURGICAL TRAINING

Internship - Surgery, Columbus, Ohio

The Ohio State University, 1969-70

Residency - General Surgery, Nashville

Vanderbilt University, 1970-1974

Fellowship - Pediatric Surgery

The Children's Hospital,

Columbus, Ohio, 1974-1976

FACULTY APPOINTMENTS

1964-1966 Laboratory Instructor, Peabody College

Nashville, TN

1974-1976 Clinical Instructor of Surgery

The Ohio State University, Columbus, $\mathrm{OH}$

1976-1979 Assistant Professor of Surgery and Pediatrics

West Virginia University, Morgantown, WV

1979-1983 Associate Professor of Surgery and Pediatrics

$1980 \quad$ Tenure granted

1983-1986 Professor of Surgery and Pediatrics

West Virginia University, Morgantown, WV

1988-1992 Professor of Surgery and Pediatrics

Director Pediatric Trauma Center

Case Western Reserve University

Cleveland, $\mathrm{OH}$

1992-1997 Professor of Surgery and Pediatrics

Program Director, General Surgery Residency

Training Program

West Virginia University

Morgantown, WV

1997-1998 Adjunct Professor of Anatomy

West Virginia University

Morgantown, WV

CERTIFICATION AND LICENSURE

1969

1976

1986
Tennessee

West Virginia

Ohio
MD6473

10948

53647 
1976

1977

\section{COMMITTEES}

\section{National}

1979-1986

1981-1986

1984-1986

1984-1988

1985-1987

1988-1991

1991-1992

1993-1997

\section{Local and State}

1982-1986

1990-1992

1992-1997
American Board of Surgery

General Surgery 9/30

Recertified 12/85

American Board of Surgery

Pediatric Surgery (6/23)

Recertified 5/1984

National Wilms' Tumor Study Group

Pediatric Oncology Group Special Disease Committee

Pediatric Oncology Group Wilms' Tumor Committee American Pediatric Surgical Association Membership/Credentials Committee American College of Surgeons SESAP VII Writing Committee American Pediatric Surgical Association Program Committee

Children's Cancer Study Group Protocol Efficiency Committee Wilms' Tumor Strategy Group, Vice-chairperson

American Pediatric Surgical Association Education Committee

American College of Surgeons

WV State Trauma Committee, Vice-chair

Academy of Medicine of Cleveland

Trauma and Emergency Care Committee

Emergency Medical Services for ChildrenTri-State Appalachian Project-

Advisory Group

Hospital Guideline Committee 


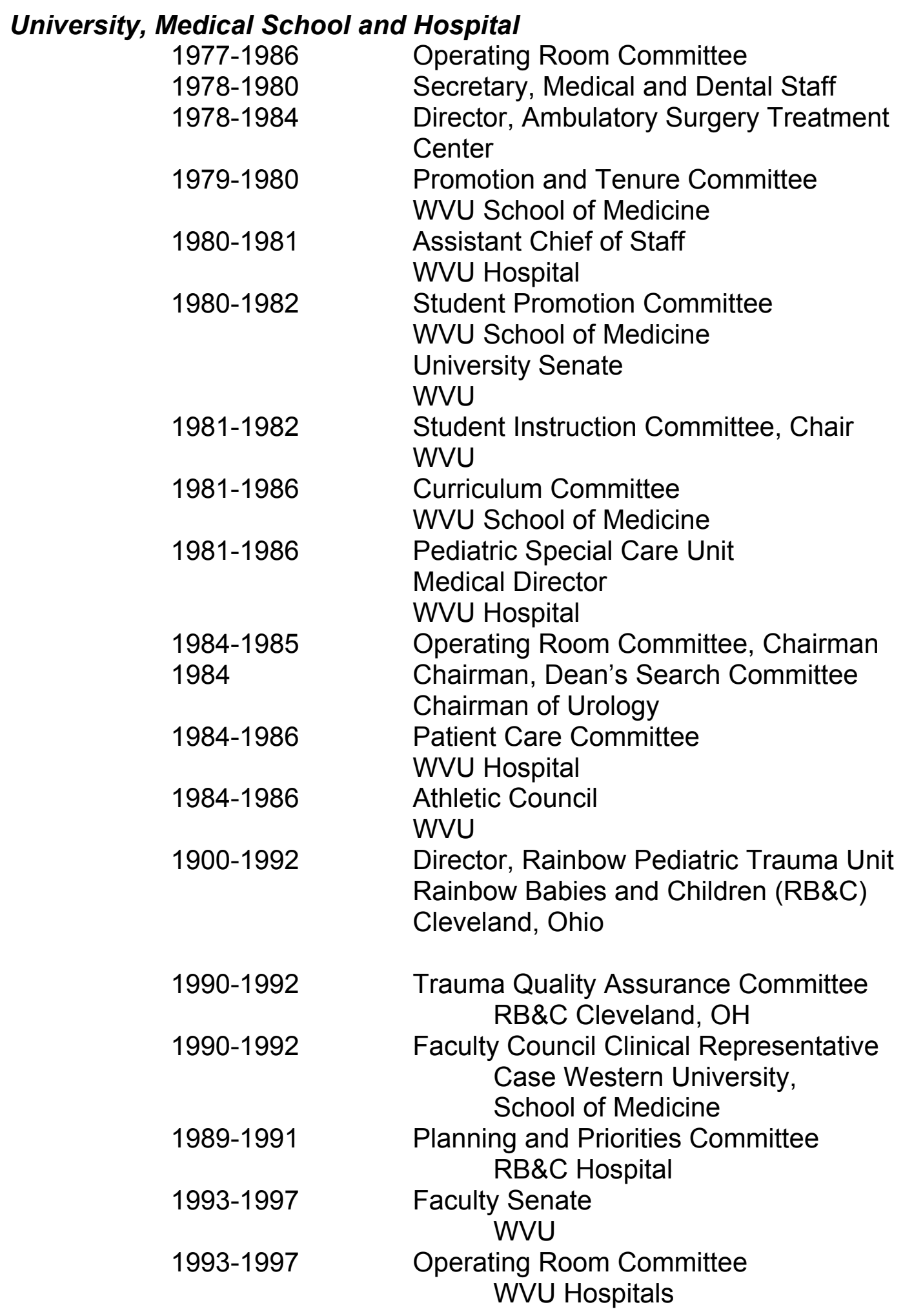

1993-1996 Curriculum Review Task Force WVU School of Medicine 

1993-1994
Curriculum Committee
WVU School of Medicine
1993-1997
Residency Review Committee
WVU School of Medicine
1994-1995
Faculty Evaluation Committee WVU Faculty Senate
1996-1997
1996-1997
Distinguished Teacher Committee WVU School of Medicine
Promotion and Tenure Committee
WVU School of Medicine

DEPARTMENTAL ACTIVITIES

1978-1984
Resident Education Coordinator
Department of Surgery
WVU

1978-1986

1982-1986

1985

1990-1992

1992-1997

1992-1997

1992-1997

1993-1997

Surgical Education Committee, Chairman

Vice-chairman for Clinical Affairs

Acting Chairman, Dept. of Surgery

Resident Education Committee

Case Western Reserve University

Program Director

Dept. of Surgery, WVU

Resident Education Committee, Chairman

Curriculum Committee

Advisory Committee on Promotion \& Tenure

\section{SOCIETY MEMBERSHIPS}

American Academy of Pediatrics, Surgical Fellow

West Virginia chapter

American College of Surgeons, Fellow

West Virginia chapter

American Pediatric Surgical Association

Association for Academic Surgery

Association of Program Directors in Surgery

Association for Surgical Education

British Association for Pediatric Surgeons

Central Surgical Association

Cleveland Surgical Association

Eastern Association for the Surgery of Trauma

$\mathrm{H}$. William Scott Society, Vanderbilt University

International Society for Pediatric Surgical Oncology

Northern Ohio Pediatric Society

Pittsburgh Surgical Society

Southeastern Surgical Congress

Forest Products Society

Society for American Forestry 


\section{HONORS AND AWARDS}

1964

1981

1982

1986-1987

1993

2002

2003

2003
Beta Beta Beta Biological Honor Society

George Peabody College for Teachers

Bernard Zimmerman Outstanding Surgical Attending, First Annual, WVU Dept. of Surgery

Alpha Omega Alpha, Medical Honor Society, Faculty Award

Research Fellowship, Department of Physiology

The Ohio State University

The Bernard Zimmerman Outstanding Surgical Attending WVU, Department of Surgery.

State Volunteer of the Year, Literacy Volunteers of West Virginia

Xi Sigma Chi Forestry Honor Society

Governor's Commendation for Volunteer Service, Literacy Volunteers

\section{SPECIAL ACTIVITIES}

1981

1982

1983

1984

1985

1988

1988

1989

1990

1992

1997
Executive Management for Women in Academic Medicine, Washington, D.C. sponsored by the American Association of Medical Colleges

Advanced Trauma Life Support Instructor

Recertified, 1988

State Trauma Faculty, West Virginia, 1982-1986

People-to-People Delegation - Europe and USSR

People-to-People Delegation - New Zealand and Australia

Representative to Chinese Medical Association, Beijing, People's Republic of China

Introduction to Laser Biophysics, Dallas, TX

Sponsored by American Society for Laser Medicine and Surgery

Chicken Embryo as an experimental model in Pediatric Surgery research. Melbourne, Australia - Workshop

Workshop on the Surgical Treatment of Anorectal Malformations. Long Island, NY

Workshop on Laparoscopic Cholecystectomy,

Case Western Reserve University

Cleveland, $\mathrm{OH}$

International Workshop on Embryology in Pediatric Surgery

Hamburg, Germany

Tutor Training, Basic Reading, Literacy Volunteers 
VOLUNTEER ACTIVITIES

1990

Surgical delegation to Guatemala

1995

Interplast Delegation to Tacna, Peru

1996-1998

Habitat for Humanity, Coordinator for Catholic Parishes HFH Project

$1997-$

Literacy Volunteers of America, tutor and board member

1998-1999

Secretary, LVA, Monongalia County Board of Directors

$1999-2000$

Vice-president, LVA Mon County Board of Directors

2000-2003

President, Mon County Board of Directors

\section{PUBLICATIONS}

Honors Thesis, George College for Teachers:

1965. Determination of Nucleic Acids in Acanthamoeba sp. during Encystment. George Peabody College for Teachers, Nashville, Tennessee

(Written in partial fulfillment of requirements for Honors Program.)

NB: There are 52 medical publications including refereed articles, book chapters and poster presentations on my Curriculum Vitae. They can be provided for anyone interested.

\section{Masters Thesis, West Virginia University}

2003. Global Demand for Certified Hardwood Products. Thesis written in partial fulfillment of the requirements for the Masters of Science in Forestry, West Virginia University, Morgantown, WV August, 2003 